\title{
Crisis communication in audiovisual format: information from Spain's National Health System on YouTube in 2020
}

\author{
Sara Loiti-Rodríguez; Aingeru Genaut-Arratibel; María-José Cantalapiedra- \\ González
}

Nota: Este artículo se puede leer en español en:

http://www.profesionaldelainformacion.com/contenidos/2021/jul/loiti-genaut-cantalapiedra_es.pdf

How to cite this article:

Loiti-Rodríguez, Sara; Genaut-Arratibel, Aingeru; Cantalapiedra-González, María-José (2021). “Crisis communication in audiovisual format: information from Spain's National Health System on YouTube in 2020". Profesional de la información, v. 30, n. 4, e300416.

https://doi.org/10.3145/epi.2021.jul.16

Manuscript received on $16^{\text {th }}$ February 2021 Accepted on $22^{\text {nd }}$ April 2021

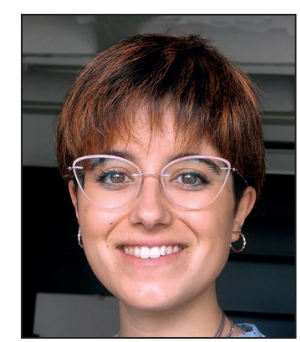

\author{
Sara Loiti-Rodríguez $\bowtie$ \\ https://orcid.org/0000-0002-7283-8211 \\ Universidad del País Vasco \\ Fac. de Ciencias Sociales y de la \\ Comunicación \\ Barrio Sarriena, s/n. \\ 48940 Leioa (Vizcaya), Spain \\ sara.loiti@ehu.eus
}

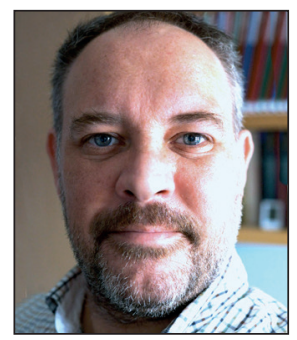

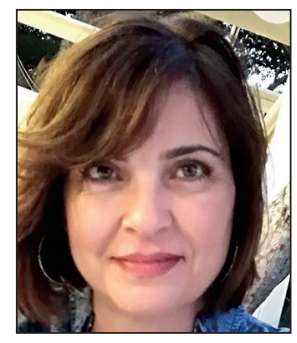

\author{
María-José Cantalapiedra- \\ González \\ https://orcid.org/0000-0003-4961-2326 \\ Universidad del País Vasco \\ Fac. de Ciencias Sociales y de la \\ Comunicación \\ Barrio Sarriena, s/n. \\ 48940 Leioa (Vizcaya), Spain \\ mariajose.cantalapiedra@ehu.eus
}

\section{Abstract}

The Covid-19 pandemic has clearly represented an unprecedented health crisis throughout 2020 that has implied great changes at both the informational and media levels. Audiovisual content has increased considerably, and health institutions have been interested in demonstrating their position as reliable and first-rate information sources. Indeed, the amount of content disseminated in just 2 months after the declaration of the pandemic exceeded that produced throughout 2019. This study describes the response to this health crisis by the Spanish National Health System on YouTube. To achieve this, the 1,035 audiovisual pieces published by official channels in 2020 were analyzed. To carry out this analysis, each piece was classified into one of seven types (from press conferences to tutorials, recommendations, informative pieces, or testimonials), while the topic covered, the format, as well as the number of views and user comments were determined. The period of greatest production corresponded to the first wave and subsequent deescalation, and the health institution that emitted most messages was the Ministry of Health with 603 videos, 170 animations, and 262 hybrid pieces combining pure video, text, and icons. Animations and hybrid pieces were the most successful messages, being used primarily as guidance to disseminate recommendations and healthy habits. The results of this study highlight the use of animations as a suitable informative resource for education and health promotion. In addition, it identifies the main weaknesses, threats, strengths, and opportunities presented by health audiovisual information on YouTube.

\section{Keywords}

Health information; Institutional information; Crisis communication; Covid-19; Coronavirus; Pandemics; Public institutions; Audiovisual communication; National Health System; Social media; Social networks; YouTube. 
Funding

This article is part of the Non-Doctor Research Personnel Predoctoral Training Program funded by the Department of Education of the Basque Government.

\section{Introduction}

The SARS-Cov2 virus, which causes Covid-19, is one of the largest pandemics in history and has rocked the world. This crisis has resulted in both an informational and media transformation by altering communication via traditional media and that of health institutions. The fundamental role of health services as authorized information sources has become more visible in the face of less reliable content and fake news (Larson, 2018; Downing et al., 2020; Nguyen; Catalán-Matamoros, 2020). During this crisis, 31\% of Spaniards used public health institutions to stay informed (Negredo et al., 2020), and $69 \%$ of them trusted the information they disseminate (Nielsen et al., 2020). The great social reach of this outreach work is evident, but one may wonder whether these messages are adequate to communicate in a clear, precise, and understandable way, and are well adapted to new communication channels such as YouTube.

\subsection{Health crisis communication}

Public institutions have a fundamental duty regarding health education and to transmit this information to society. This is an obligatory public function because it addresses a fundamental right described in article 43 of the Spanish Constitution. Indeed, General Health Law 14/1986 states that

"the promotion of health (...) through adequate health education of the population" ["Ia promoción de la salud (...) mediante la adecuada educación sanitaria de la población"] (Spain, 1986, p. 13)

is part of their functions. On the other hand, General Public Health Law 33/2011 goes further, specifying that

"the health administrations (...) will ensure that the information is adapted socially, culturally, and linguistically to the targeted sectors of the population" ["las administraciones sanitarias (...) velarán por que la información esté adaptada social, cultural y lingüísticamente a aquellos sectores de la población destinatarios de la misma"] (Spain, 2011, p. 16).

In addition, institutional information is essential to safeguard the security and control of society in any emergency situation, representing one of the pillars of the response to such situations through a communication plan that guarantees adequate management of the information supplied to the population and media (Ibáñez-Peiró, 2020, p. 305). For any institution, "communicating is a professional and ethical requirement" ["comunicar resulta una exigencia profesional y ética"] (Rodríguez-Andrés, 2017, p. 367), and in the event of a health crisis its importance becomes even greater. Such information must always be presented in a sensitive and relevant fashion, since it can influence the understanding and acceptance of the problem, or generate concern and social alarm, depending on its presentation (Quinn, 2008).

Crisis communication is an area of great academic interest where the importance of establishing an adequate information strategy has been demonstrated (Coombs; Holladay, 2012; Coombs, 2014), as well as the use of multiple channels via adapted content (Seeger; Reynolds, 2008; Costa-Sánchez, 2010; Fernández-De-la-Hoz, 2014). Many of these approaches are based on studies of the treatment of information and institutional communication during previous epidemics such as Ebola (Costa-Sánchez; Rodríguez-Vázquez; López-García, 2015; Micaletto-Belda; Gallardo-Vera, 2015; Percastre-Mendizábal; Pont-Sorribes; Suau-Gomila, 2019) and influenza A, among others (Costa-Sánchez, 2011; Mestre-Ortega et al., 2018).

The Covid-19 pandemic has directly influenced the production of articles and other scientific texts, from case studies focused on specific geographical areas (Farhana; Mannan, 2020; Salva et al., 2020), contributions on educational and university issues (Bernat, 2020; Casajús;

Public institutions have a fundamental duty regarding health education and in transmitting this information to society

Giorgi, 2020; Montacute, 2020), analyses related to other health problems (Ky; Mann, 2020; Pakpour; Griffiths; Lin, 2020; Stein, 2020), and even questions about inequality, hatred, and racism (Garzaniti; Díaz-Ledesma; Navarro-Martínez, 2020; Ziems et al., 2020). The presentation of information about the pandemic has been studied as it relates to both the media (Fusté-Forné, 2020; Manrique-Grisales, 2020; Masip et al., 2020) and institutional public communication (Ibáñez-Peiró, 2020; Lagneaux, 2020; Peñafiel-Saiz; Ronco-López; Castañeda-Zumeta, 2020), corporate communication and public relations (Costa-Sánchez; López-García, 2020; Xifra, 2020), and social networks (Cinelli et al., 2020; Peña-Lillo, 2020; Thelwall; Thelwall, 2020). Note that many of these scientific contributions have focused on reflections regarding the spread of false news or hoaxes, which has become such a concern that their spread related to the new coronavirus has given rise to a new concept: the infodemic (Andreu-Sánchez; Martín-Pascual, 2020; Ramón-Fernández, 2020; Salaverría et al., 2020; Sánchez-Duarte; Magallón-Rosa, 2020; Singh et al., 2020), although many other contributions have also sought to determine the what, who, and how of information dissemination via new media (Cui; Lee, 2020; González-Romo; Iriarte-Aguirre, 2020). 
It seems clear that all public institutions or organizations in general, but those responsible for healthcare in particular, require

"Professional communication management that enables them to interact effectively with the media and transfer their messages to the public consciousness" ["una gestión profesional de la comunicación que le [s] permita relacionarse eficazmente con los medios y trasladar sus mensajes a la opinión pública"] [Rodríguez-Andrés, 2017, p. 368).

This requirement should not only occur via traditional media (press, television, and radio) as institutions can now also achieve this (Jardón, 2017, p. 581) via social networks (Twitter, Facebook, YouTube, etc.) as well as their official websites, enabling them to interact and collaborate with citizens directly. Regarding information on health crises, these new trends were already noticed in 2014 with the Ebola outbreaks, and Nespereira-García (2015, p. 230) already admitted that that

"health and communication crisis (...) has shown the limitations of the traditional models of health risk communication". ["crisis sanitaria y de comunicación (...) ha evidenciado las limitaciones de los modelos tradicionales de la comunicación del riesgo sanitario"]

This observation has become more evident in the case of Covid-19, and the media and institutions have been forced to change both their communication strategies and policies at all scales, including in the audiovisual field.

\subsection{YouTube as an institutional communication channel during the coronavirus pandemic}

In recent years, the use and presence of online social networks have increased because of the relevance that information and communication technologies have acquired in daily life (Cantor-Silva; Pérez-Suárez; Carrillo-Sierra, 2018). The quick and easy circulation of messages favors their dissemination, repercussion, impact, and reactions among the public (Picazo-Sánchez, 2016, p. 314). More than half of the population with Internet access actively use social networks, representing 3,800 million people, and in 2020, the number of users increased by $9.2 \%$ compared with the previous year (Kemp, 2020). In the case of Spain, there are 25.9 million active users, representing $87 \%$ of Internet users aged $16-65$ years, and $66 \%$ use social networks to stay informed (IAB Spain, 2020). We are currently immersed in a multiscreen and multiplatform world where the relationship between institutions and society has been completely altered by new habits of information consumption, since online media have become "common information channels" ["canales de información al uso"] (Flores-Vivar, 2017, p. 64), surpassing traditional routes for the first time (Negredo et al., 2020).

It is thus necessary for institutions to adapt their communication to the informational needs of today's society. They must develop innovative strategies and test new communication formats to guarantee their presence in an environment that is as competitive as the digital world. The use of animations, infographics, and videos to present facts in a more attractive and striking way is increasingly common (Costa, 2014, p. 91). Indeed, the use of new formats and innovation to capture attention and encourage user participation

"has guaranteed the success, from the informational point of view, of platforms such as Vimeo, Blip.tv, Viddler, and above all, YouTube" ["ha[n] garantizado el éxito, desde el punto de vista informativo, de plataformas como Vimeo, Blip.tv, Viddler y, sobre todo, YouTube"] (Ruivo-Manzano; Gomes-Franco-e-Silva, 2019, pp. 37-38).

YouTube is the second most widely used social network, with 2,000 million users, and in the case of Spain, it is the most highly valued, with 8.4 points out of 10 (IAB Spain, 2020), having 30 million followers (Kemp, 2020). Although it remains a "pending challenge for most journalists" ["reto pendiente para la mayoría de periodistas"] (Blanco; Palomo, $2019, \mathrm{p}$. 8), it has become a fundamental channel for their documentation work (Lope-Salvador; Gabelas-Barroso; Bernad, 2018, p. 55), for the creation, presentation, and diffusion of new genres (Paredes-Otero, 2019, p. 56), and to promote the interactivity and personalization of content (Marfil-Carmona; Osuna-Acedo; Ortiz-Sobrino, 2018, p. 196). Our starting point is that YouTube should be considered to be a social network as well as a channel because, although it is used primarily as an audiovisual broadcasting and viewing platform, it also allows user interaction to a lesser or greater extent.

Although other social networks such as WhatsApp, Facebook, and Twitter are used more widely, 26\% of Spanish Internet users have used YouTube to find news, developments, or explanations about Covid-19 (Negredo et al., 2020). Articles have been published on audiovisual communication via YouTube (Nascimento-Junior et al., 2020; Orduña-Malea; Font-Julián; Ontalba-Ruipérez, 2020), but there is no information regarding what and how this has been carried out by health institutions in Spain.

\subsection{Objectives and study sample}

The aim of this study is to describe the response to this health crisis by the Spanish National Health System on YouTube. To achieve this, the following specific objectives are defined:

- To quantify and perform a metric analysis of the audiovisual pieces disseminated by public health institutions during 2020.

- To identify and characterize their format.

- To establish a typology of all the published content.

- To determine the degree of participation and interaction of users. 
This work thus aims to describe the what, when, and how of the reporting of the National Health System via its official YouTube channels in 2020, and the degree of acceptance and interest that this content received. To construct the list of channels, we used those explicitly identified on the websites of the institutions. In addition, to obtain a more exhaustive list, a specific search was also carried out on YouTube. As a result, all the audiovisual content on 17 channels -that of the Ministry of Health and the 16 regional health services with an official channel- were analyzed, from the report of the first case in Spain on 31 January until 31 December 2020.

Table 1. Subscriptions, views, and content broadcast on the official channels of the Spanish National Health System on YouTube (2020)

\begin{tabular}{|c|c|c|c|}
\hline \multirow[b]{3}{*}{ YouTube channels of the National Health System } & \multirow{2}{*}{\multicolumn{3}{|c|}{ Total in 2020}} \\
\hline & & & \\
\hline & Subscribers & Views & Covid 19 pieces \\
\hline Andalusian Health Service & 26,518 & 6,162 & 2 \\
\hline Rioja Health & 23,200 & 8,738 & 6 \\
\hline Ministry of Health & 11,300 & $4,907,608$ & 301 \\
\hline Osakidetza-Basque Health Service & 8,340 & 783,689 & 31 \\
\hline Catalan Health Service & 7,050 & $1,126,231$ & 228 \\
\hline Sergas-Galician Health Service & 6,940 & 44,470 & 41 \\
\hline Madrid Health Service & 6,680 & 564,095 & 87 \\
\hline Navarra Health & 6,600 & 58,126 & 72 \\
\hline Murcia Health & 966 & 107,983 & 189 \\
\hline Castilla-La Mancha Health Service & 270 & 75 & 2 \\
\hline Aragon Health Service & 233 & 42 & 1 \\
\hline Balearic Islands Health Service & 168 & 15,328 & 34 \\
\hline Canary Islands Health Service & Not visible & 78,846 & 28 \\
\hline Department of Universal Health and Public Health of the Valencian Community & Not visible & 24,189 & 12 \\
\hline Cantabria Health Services & \multicolumn{2}{|c|}{ Does not report on Covid 19} & 0 \\
\hline Castilla and Leon Health Service & \multicolumn{2}{|c|}{ Does not report on Covid 19} & 0 \\
\hline Extremadura Heath Service & \multicolumn{2}{|c|}{ Does not report on Covid 19} & 0 \\
\hline Astursalud-Health Portal of the Principality of Asturias & \multicolumn{2}{|c|}{ Does not have a channel } & 0 \\
\hline Ceuta Health Area & \multicolumn{2}{|c|}{ Does not have a channel } & 0 \\
\hline Melilla health area & \multicolumn{2}{|c|}{ Does not have a channel } & 0 \\
\hline
\end{tabular}

\section{Methodology}

This work approaches the study of the health information emitted by the official channels of the Spanish National Health System on YouTube through a descriptive quantitative method, which seeks to characterize and specify the properties of this phenomenon by recording, measuring, and evaluating various aspects of it (Batthyány; Cabrera, 2011, p. 33). To achieve this, a methodological form was prepared with the aim of identifying and cataloging the pieces published by Spanish health institutions during the new coronavirus pandemic. Tabulation of these data enables a comparison of how the format of this content is related to the type of information shared (Berganza-Conde; García-Galera, 2005). This makes it possible to identify both the strengths and weaknesses of the audiovisual content emitted by the National Health System.

\subsection{Method and analysis form}

Many studies have presented proposals for how to adapt information to the audiovisual format of YouTube; for example, Costa (2014, p. 87 et seq.) takes as a reference some of the most successful channels and lists the characteristics that videos must have to be more effective and generate more views:

- Short duration.

- Be subtitled.

- Encourage interactivity on both YouTube and other social networks.

- Include keywords, labels, or tags.

- Encourage user participation through innovation and the use of new formats such as animations, infographics, and moving images.

On the other hand, to address the question of content analysis, the methodological proposals presented in the works of Arévalo-Salinas (2017, pp. 27-30) and Paredes-Otero (2019, pp. 61-63) have been very useful: the former describes discursive strategies as part of the object of study, while the latter gives special prominence to the theme and typology of the videos. However, these contributions focus on very diverse topics that are not directly related to the present investigation. The former deals with the audiovisual production of social movements, while the latter talks about content 
disseminated via specialized media in video games, meaning that both their thematic classification and the typology presented are limited to those works.

For this reason, to prepare the analysis form for this research, the categories of document number, title, date, and duration were included, along with the topic, the language of the video, and the source organization. To study their consumption and user interaction, the numbers of views, reactions (likes and dislikes), comments, and subscribers were collected as variables, as used previously in other studies (Tur-Viñes; Gónzalez-Río, 2020, p. 8).

However, to adapt this research to the analysis of institutional health information, a series of categories was created to study the descriptive dimension of the content.

To provide a complete overview of the types of videos offered by the studied channels, after an initial inspection of the pieces broadcast, the classic genres of the journalistic world were included (news, reports, and interviews) as well as those from other areas of communication such as public relations, advertising (press conferences and spots), or the academic and musical world (scientific communication and songs). We also included those that, although they cannot be considered exclusive to new media, are common on channels such as YouTube: informative pieces that do not necessarily correspond to traditional journalistic genres, which we call information; tutorials, recommendations, and advice; and mixed pieces that combine different types. In addition, we include those that, although traditionally part of the journalistic genres, are now presented independently and explicitly: testimonies and acknowledgments. In this way, a content classification consisting of 13 categories was created.

With regard to format, although in traditional media there is a tendency to classify audiovisual content into two main types (videos and animations), an initial inspection forced us to distinguish and qualify the meaning of the former by distinguishing between hybrid pieces (where pure video is combined with graphical elements such as texts and icons) and pure videos (unedited and made up exclusively of real images). Thus, three formats were differentiated for this study: videos, hybrid pieces, and animations.

Finally, the target audience was classified into four categories that correspond to the classic profiles: internal (professionals) and external (patients) institutional health communication, users, and citizens. The latter three differ in that a patient has a direct relationship and personal need, a user is not really a patient but has a direct relationship resulting from the needs of others (whether due to care or family responsibilities), while a citizen has an indirect relationship with the health system but needs information regarding health promotion and disease prevention. We thus understand that, if the pieces are not explicitly addressed towards a specific audience (patients, users, or professionals), they are by definition aimed at the whole of society (citizens).

Thus, a methodological form was designed with 20 descriptive variables, divided into three main blocks, as presented in Table 2 .

\subsection{Data collection}

The data from the 17 official channels, previously encoded using the mentioned variables for statistical analysis, were collected and analyzed using the SPSS program for three phases: June and October 2020, and January 2021. This enables an exhaustive study by analyzing both single variables and their frequencies, as well as the relations between variables via contingency tables. Note that all the correlations achieve a confidence level of $95 \%$ with a chi-squared estimation of the probability of association between variables of $\leq 0.05$, representing statistical significance (Babbie; Wagner; Zaino, 2018, pp. 274-282).
Table 2. Analysis form for audiovisual content emitted by Spanish health institutions on YouTube

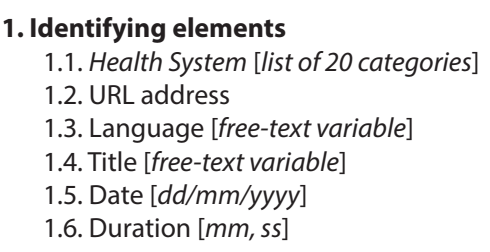

2. Consumption of and interactions with the pieces

2.1. Views [numerical value]

2.2. Reactions [numerical value]

2.2.1. Number of likes

2.2.2. Number of dislikes

2.3. Comments [numerical value]

3. Description of content

3.1. Format [list of 3 categories]

1. Video

2. Animation

3. Hybrid piece

3.2. Typology [list of 13 categories]

1. Press conference

2. Recommendations

3. Information

4. Mixed pieces

5. Tutorials

6. Testimonials

7. Acknowledgements

8. Advertising

9. Scientific communication

11. Songs

12. Appearances

13. Reports

3.3. Topic [free-text variable]

3.4. Target audience [patient, user, citizen, or healthcare professional]
10. Interviews 


\section{Results: audiovisual treatment of the pandemic by the Spanish National Health System on YouTube in $\mathbf{2 0 2 0}$}

Since the first positive case was announced in Spain, on 31 January, until the end of the year, 1,035 audiovisual pieces about Covid-19 were published by the 17 official channels of the National Health System on YouTube. Of all the channels, the one that emitted most content was that belonging to the Ministry of Health, Consumption, and Social Welfare (29\%), while the most active regional health services included those of Catalonia (22\%) and Murcia (18\%). Note that the health services of three autonomous communities (Cantabria, Castilla and Leon, and Extremadura) did not report on the new coronavirus on YouTube. Therefore, a total of 14 health institutions published some content on the pandemic on this social network (Figure 1).

Likewise, it is during the first four-month period (coinciding with the so-called first wave) when the greatest amount of information was emitted by health institutions. Note that April was the month in which the highest number of audiovisual pieces on Covid-19 was shared (25\%), and that the institutions produced and disseminated most of the information from March to June, a period that corresponded to $68 \%$ of all audiovisual content emitted in 2020 (Figure 2).

\subsection{Descriptive characteristics of the audiovisual content presented by health institutions}

\subsubsection{Format and content types}

Of the 1,035 audiovisual pieces broadcast during 2020, 603 were pure videos (without editing), representing $58 \%$ of the total, while $170(17 \%)$ were animations (synthetic content in motion), and $262(25 \%)$ were hybrid pieces in which pure video, text, and icons are combined (Figure 3).

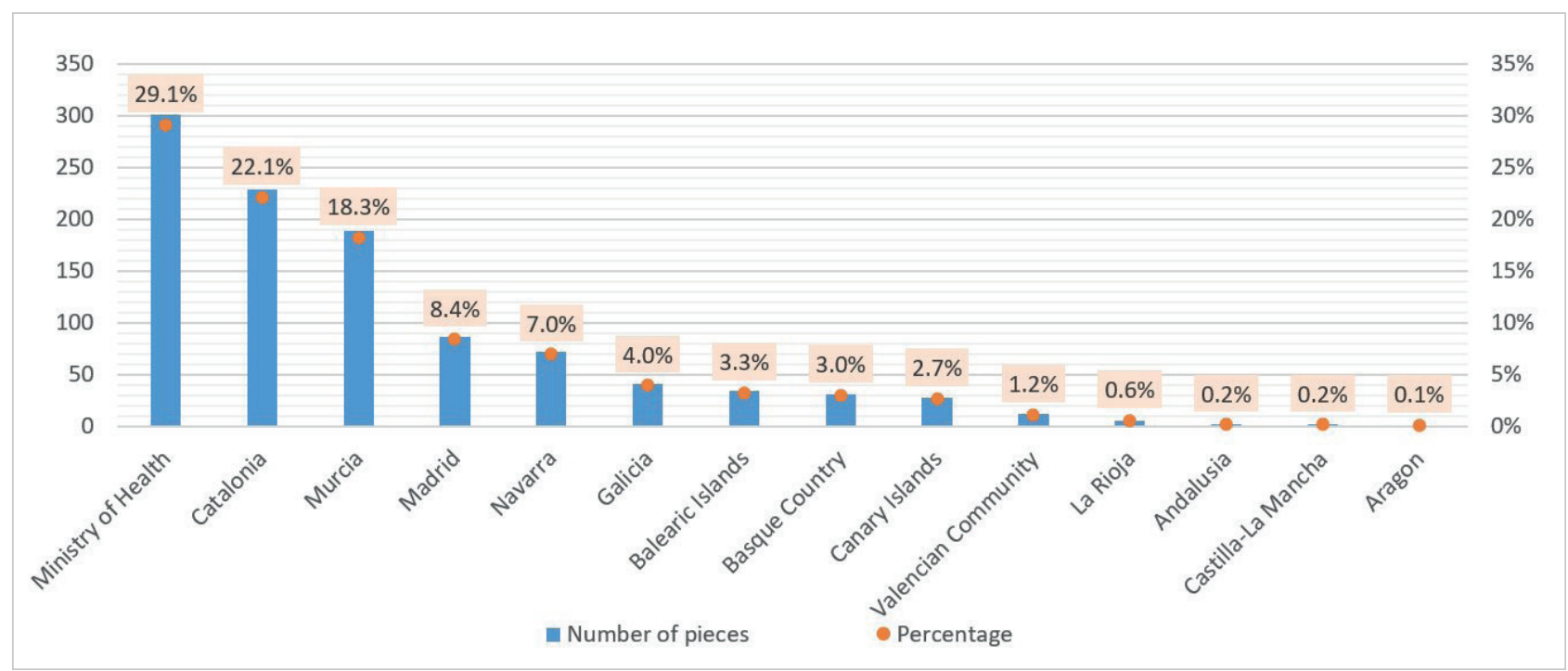

Figure 1. The production of YouTube channels belonging to the National Health System in 2020

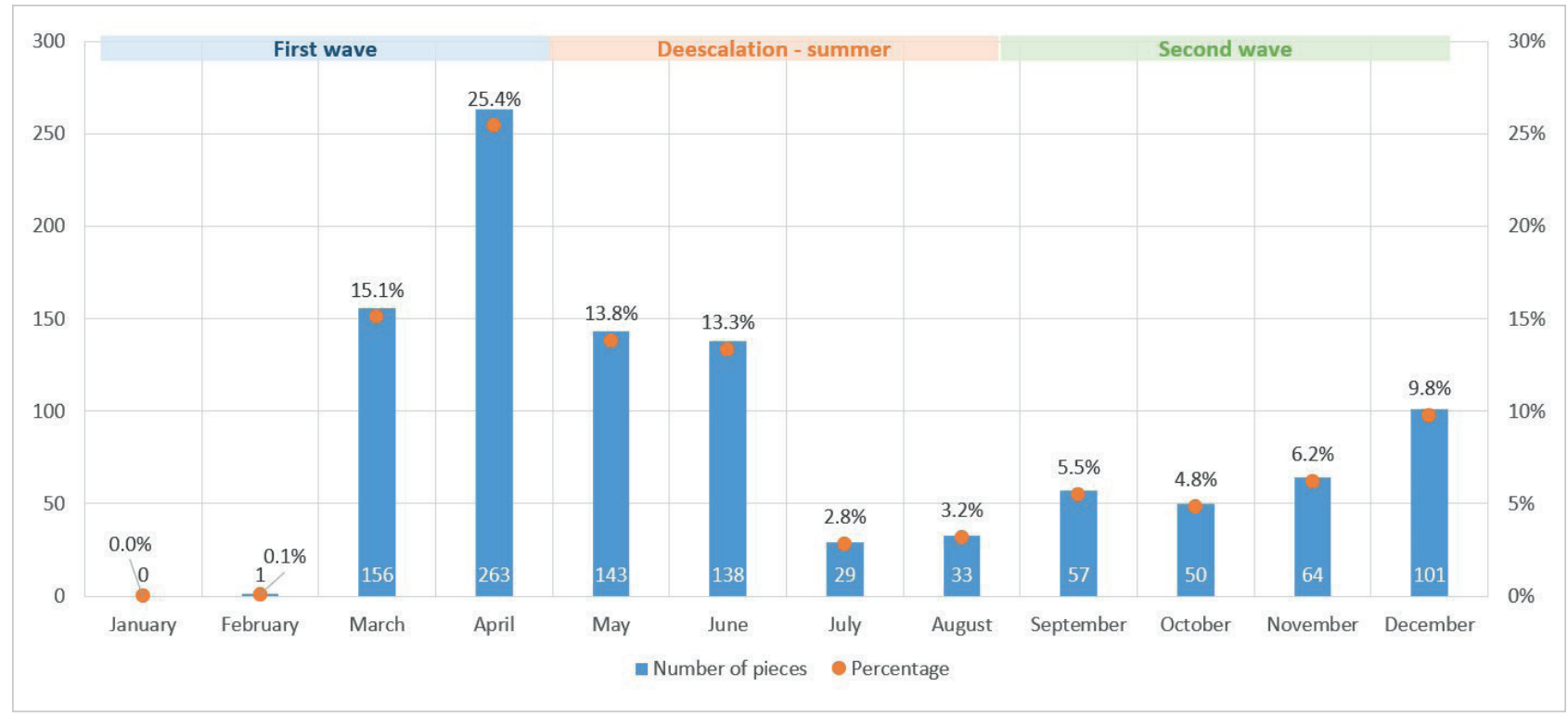

Figure 2. Evolution of audiovisual production in 2020 


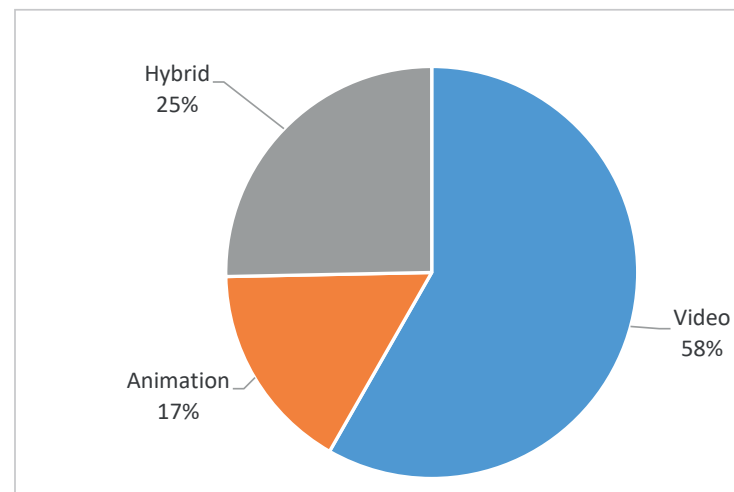

Figure 3. Format (\%)

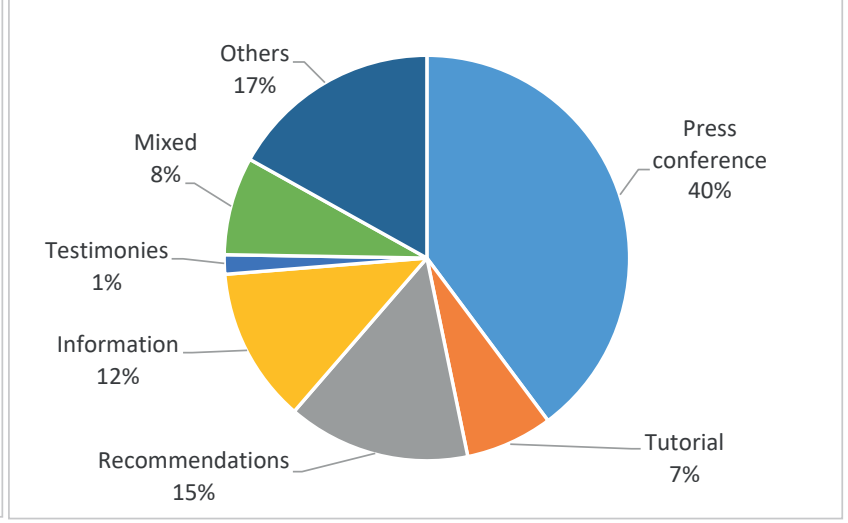

Figure 4. Content type (\%)

Regarding their type, it was noted that $40 \%$ were press conferences while $17 \%$ corresponded to the category Other, including spots, video tributes, songs, political appearances, interviews, and scientific communications. The figure below describes the pieces that provided health prevention recommendations (15\%), while purely informative content $(12 \%)$ is presented thereafter in Figure 4.

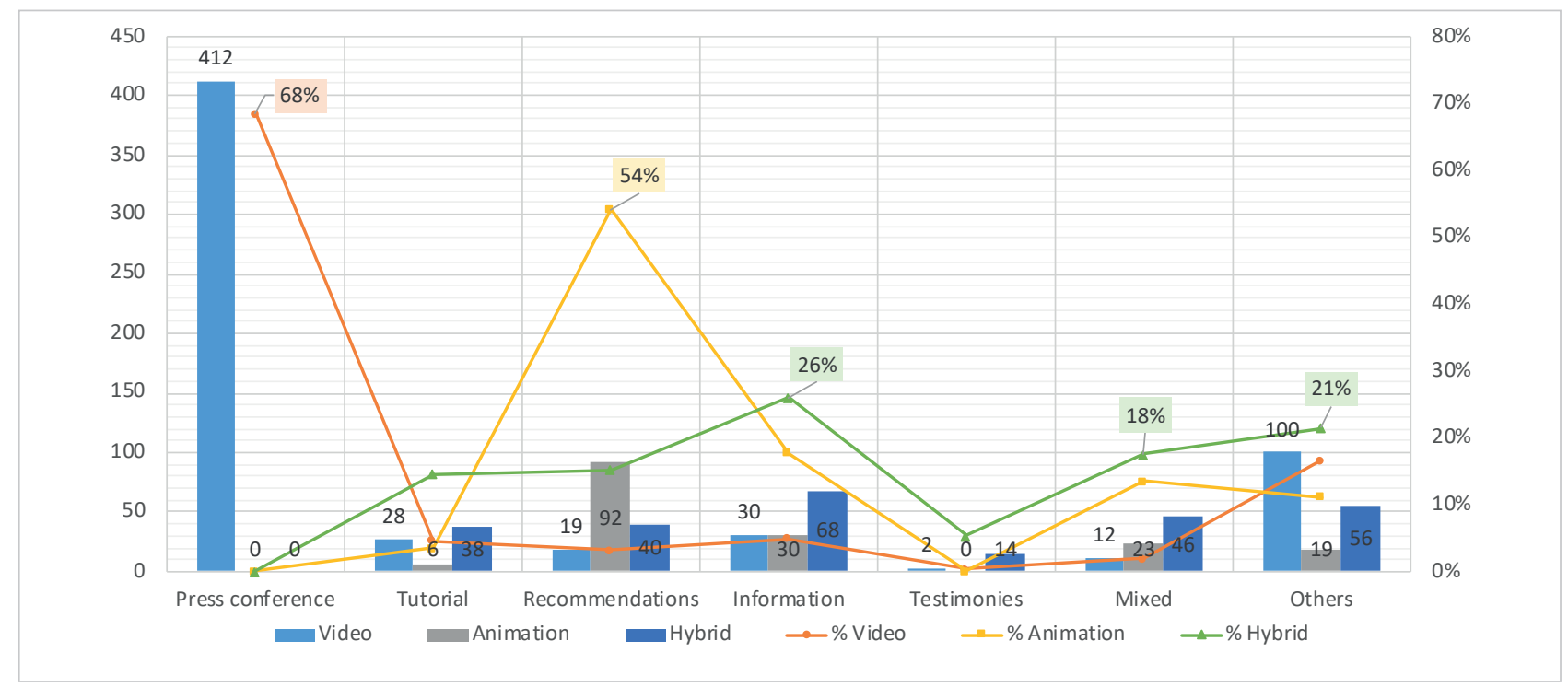

Figure 5. Format according to type of content

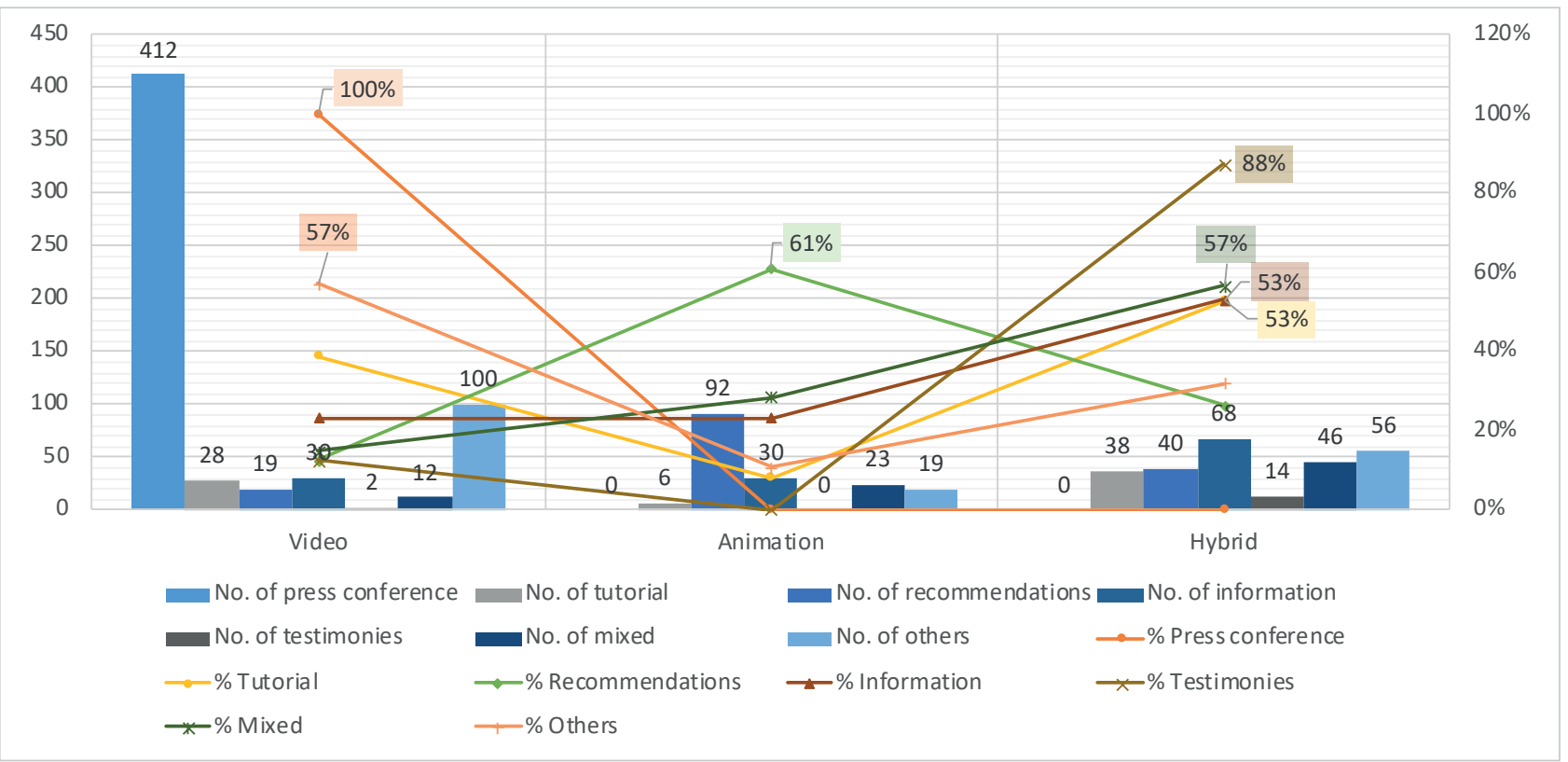

Figure 6. Content type according to format 
It was found that $68 \%$ of the pure videos (without processing) were press conferences, while most of the animations (54\%) aimed to provide recommendations and advice on good habits to avoid infection. Hybrid pieces were used regardless of the type of content: $26 \%$ being used to disseminate information, $21 \%$ to offer tutorials on exercises, handling, and use of personal protection equipment, among others, and $18 \%$ to share mixed content (information and recommendations) (Figure 5).

In the same way, flipping the data to take the type of content as a reference revealed that $100 \%$ of the press conferences and $38 \%$ of the category Others (acknowledgments, advertising, and scientific communications) was presented through videos. Animations were used to disseminate recommendations in most cases (61\%). Finally, $88 \%$ of the testimonies were presented as hybrid pieces, followed by mixed pieces (information and recommendations) (57\%), information (53\%), and tutorials (53\%) (Figure 6).

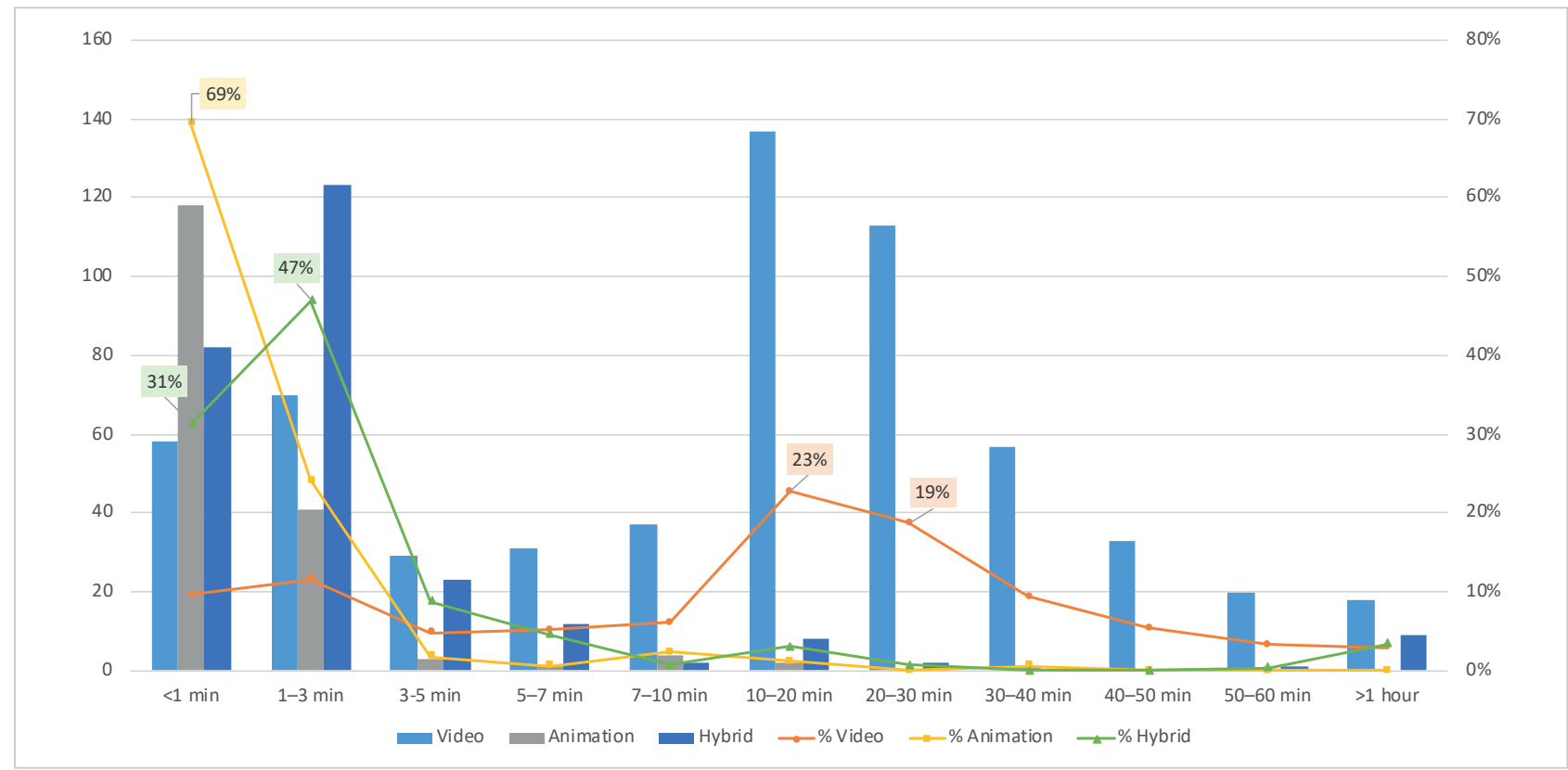

Figure 7. Duration of the pieces according to their format

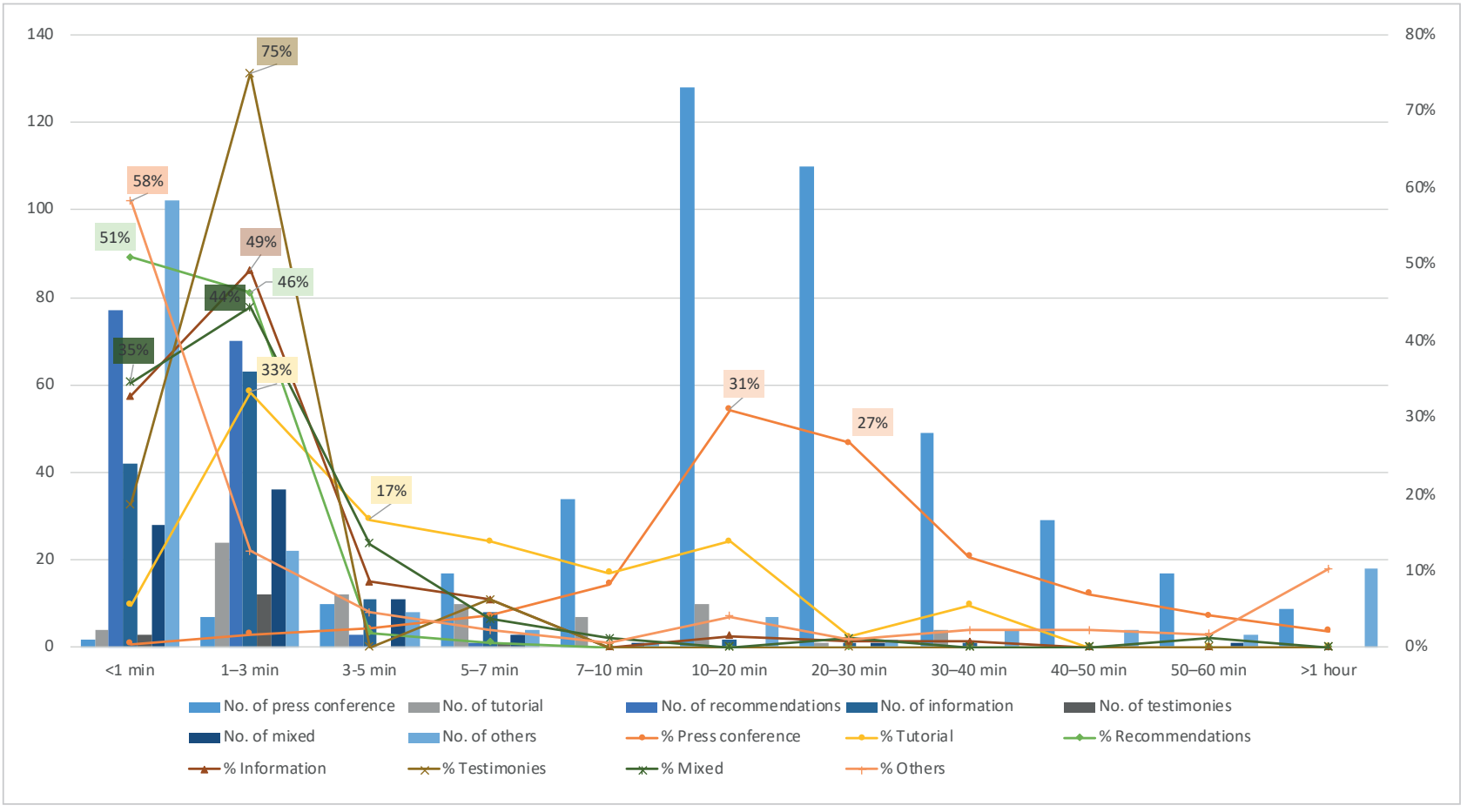

Figure 8. Duration of pieces according to type of content 


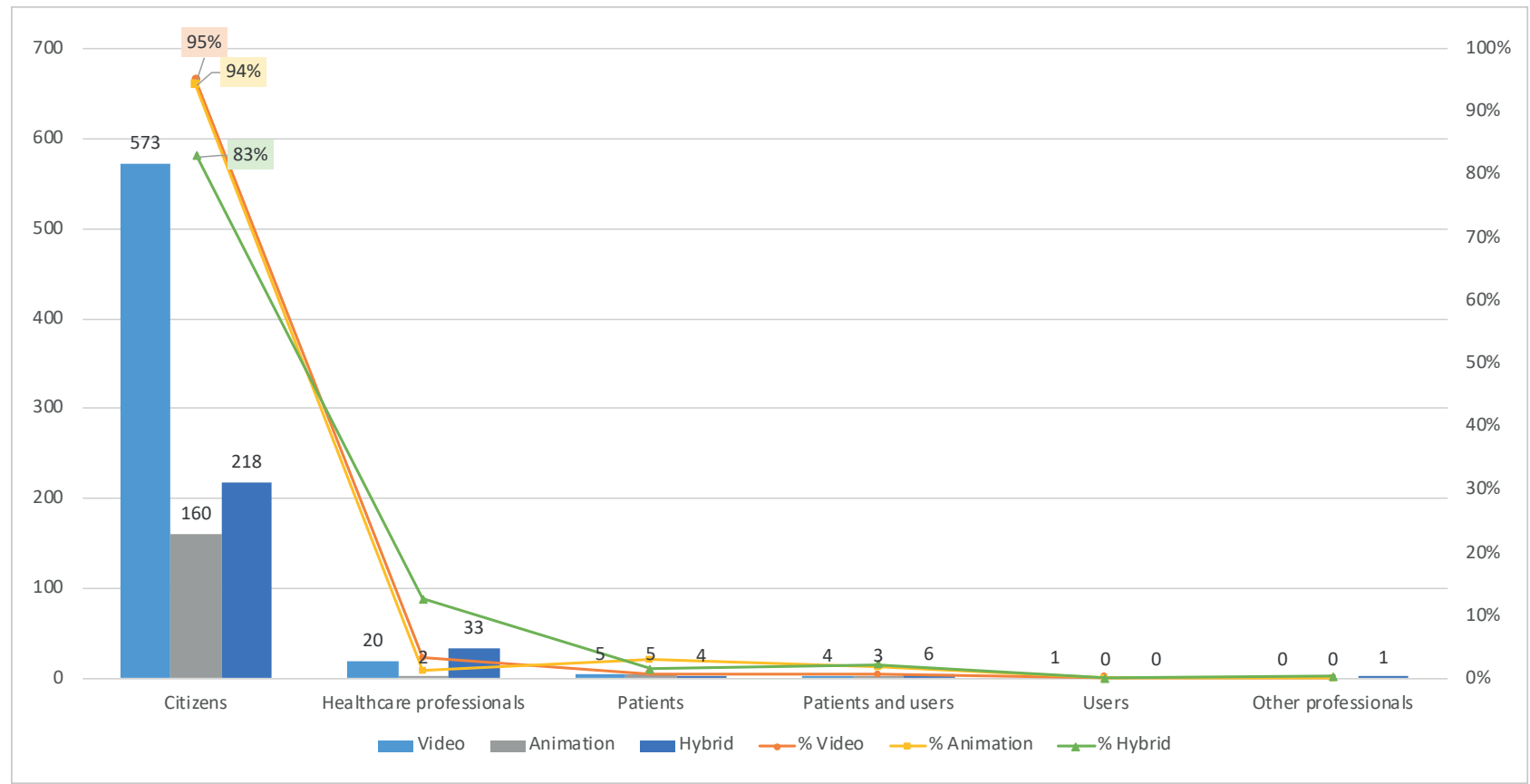

Figure 9. Formats according to their audience

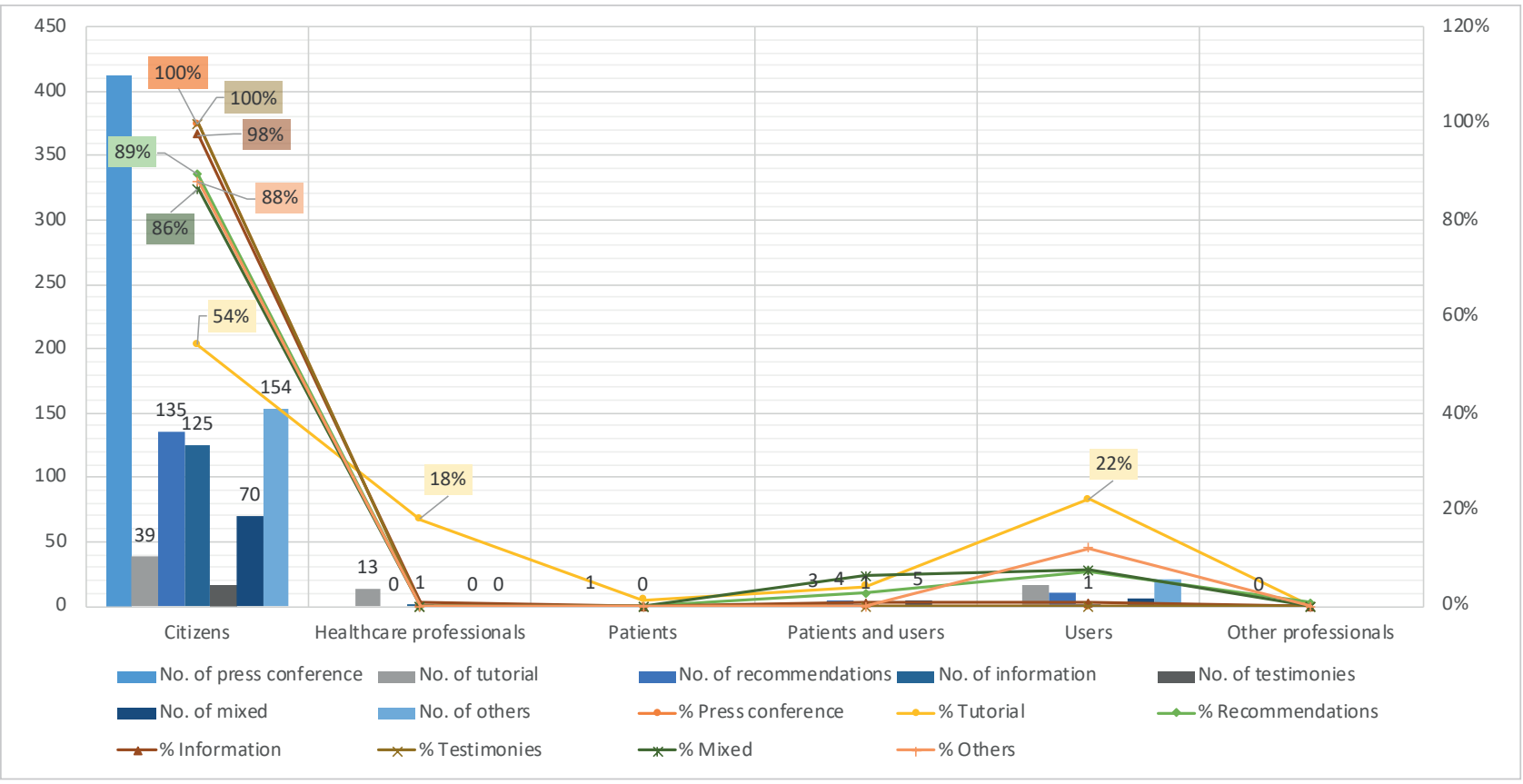

Figure 10. Types of content according to their audience

\subsubsection{Duration, topic, and target audience of the content}

Of the emitted pieces, $53 \%$ had a duration of less than 5 minutes, but they most commonly did not exceed 3 minutes (47\%). Depending on their format, the videos were characterized by longer durations, with $42 \%$ lasting $10-30$ minutes, whereas $69 \%$ of the animations lasted less than 1 minute and $47 \%$ of the hybrid content lasted $1-3$ minutes (Figure 7 ).

On the other hand, $97 \%$ of the recommendations, $79 \%$ of the mixed pieces, $75 \%$ of the testimonials, and $49 \%$ of the informative lasted no longer than 3 minutes. Of the tutorials, $50 \%$ did not exceed 5 min, while $58 \%$ of the press conferences lasted 10-30 $\mathrm{min}$ (Figure 8).

The published content showed great thematic variety, but always with the coronavirus as a central axis, from pieces offering advice to promote healthy habits and safety measures to avoid infection, to pieces expressing gratitude and tribute to professionals, sick people, or victims, through recommendations on the use and handling of personal protective equipment. Other pieces informed about what Covid-19 is and its symptoms, prevention, and relationship with other diseases, and even video tutorials for applications and websites to carry out administrative procedures. 
Regarding the target audience, $92 \%$ of all the content was directed towards citizens, that is, the entire society. This finding did not depend on the format or type, since $95 \%$ of videos, $94 \%$ of animations, and $83 \%$ of hybrid content (Figure 9), as well as $100 \%$ of press conferences and testimonials, $95 \%$ of information, $89 \%$ of recommendations, $86 \%$ of mixed content, and $89 \%$ of the Others category were aimed at all citizens. However, the tutorials exhibited a certain difference, with $22 \%$ being addressed towards health professionals (Figure 10).

\subsection{Consumption and user interaction}

Regarding the number of views, $77 \%$ had fewer than 1,000 and $64 \%$ fewer than 500 , with $13 \%$ having between 500 and 1,000 (Figure 11).

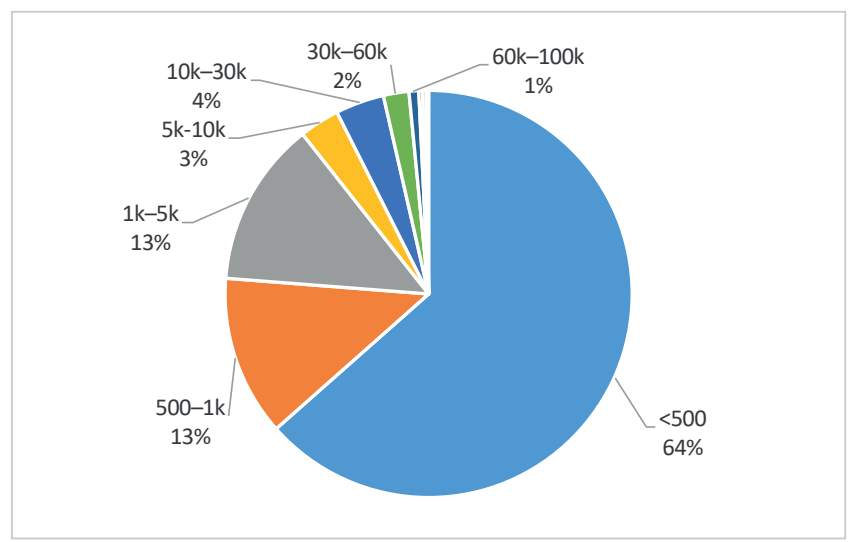

Figure 11. Number of content views

Regarding reactions from users, $95 \%$ of the content received fewer than 50 likes, $79 \%$ fewer than 10 , and $16 \%$ between 10 and 50, while $98 \%$ received fewer than 50 dislikes, $92 \%$ fewer than 10, and 6\% between 10 and 50, revealing that there was not a great difference between the number of positive and negative reactions (Figure 12).

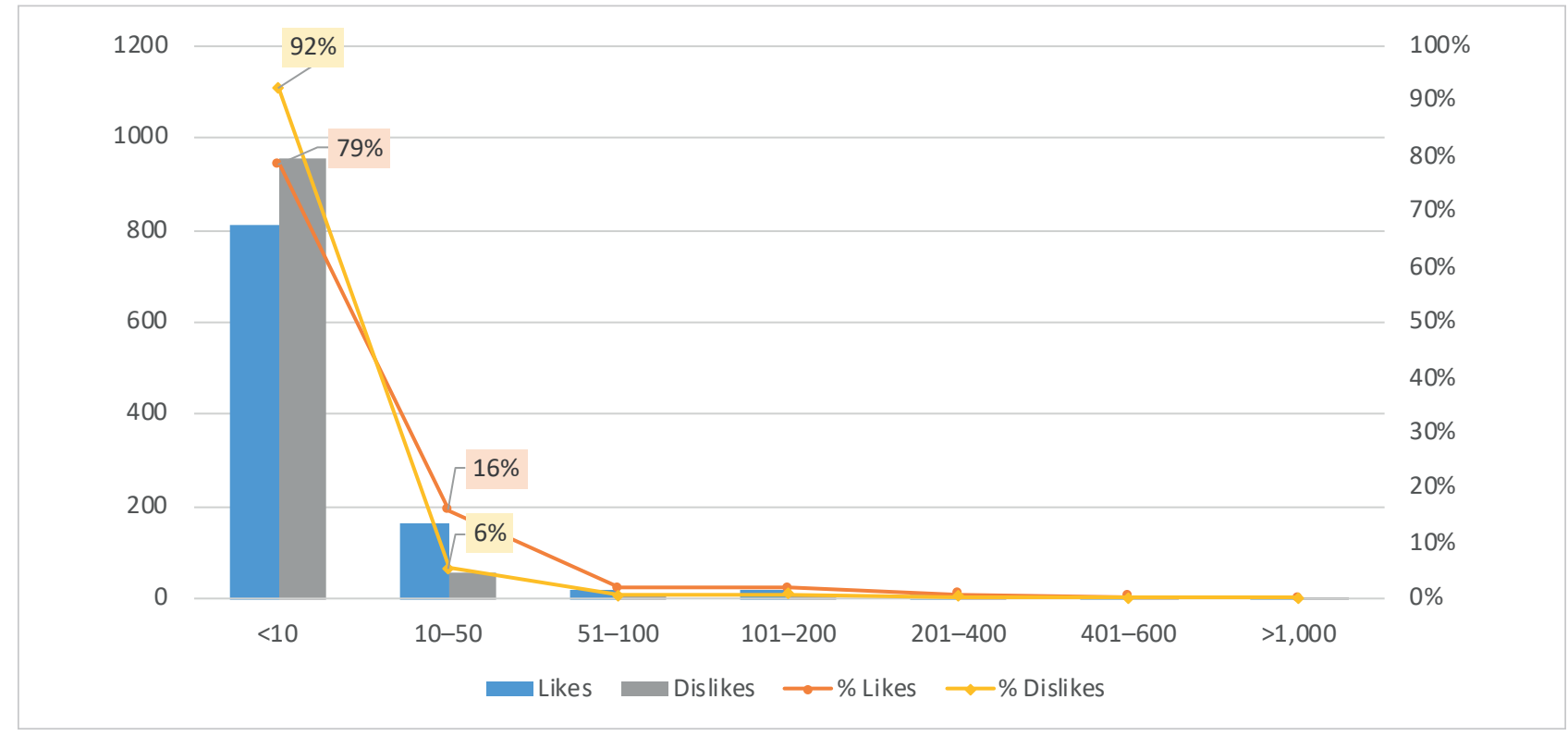

Figure 12. Number of reactions to the content

Meanwhile, comments were disactivated for $60 \%$ of the content, while no comments were made in $95 \%$ of the cases where it was possible (Figure 13). Eight of the 14 institutions that shared pieces about the coronavirus deactivated the option to comment on $100 \%$ of their content (Andalusia, Aragon, Catalonia, Valencian Community, Galicia, Madrid, Murcia, and the Basque Country). The other health services allowed users to make contributions to most of their content: Balearic Islands, Canary Islands, and Castilla-La Mancha (100\%), the Ministry of Health (97\%), La Rioja (83\%), and Navarra (72\%).

Animations and hybrid pieces received a greater number of views (by up to $30 \%$ ) than videos (Figure 14). By type of content, $78 \%$ of the recommendations and $76 \%$ of the tutorials were visited up to 5,000 times (Figure 15), while the average number of views of all the content did not exceed 500 (63\%).

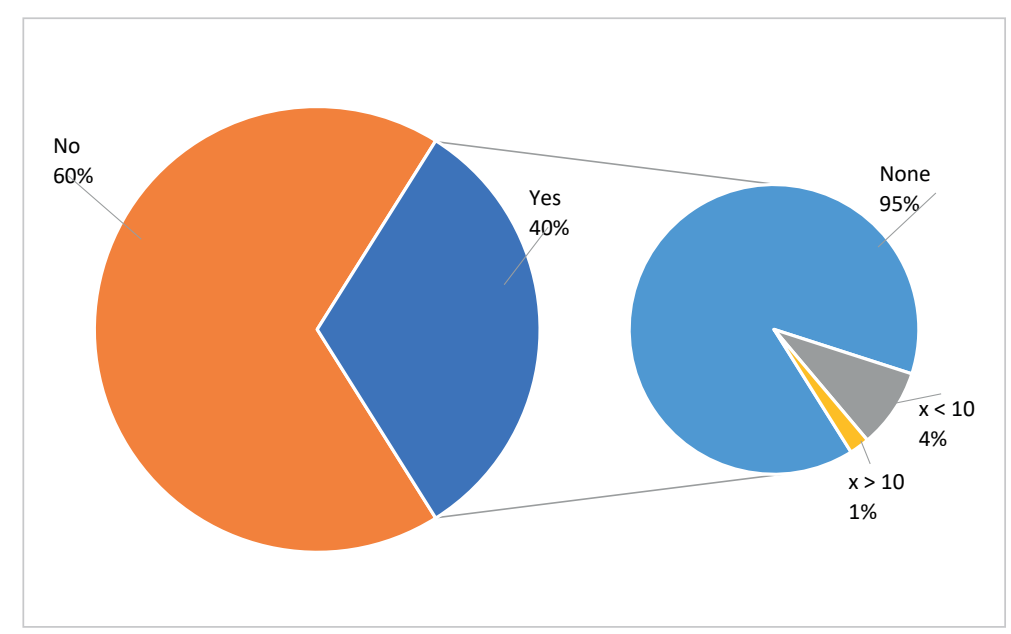

Figure 13. Activation and number of comments 


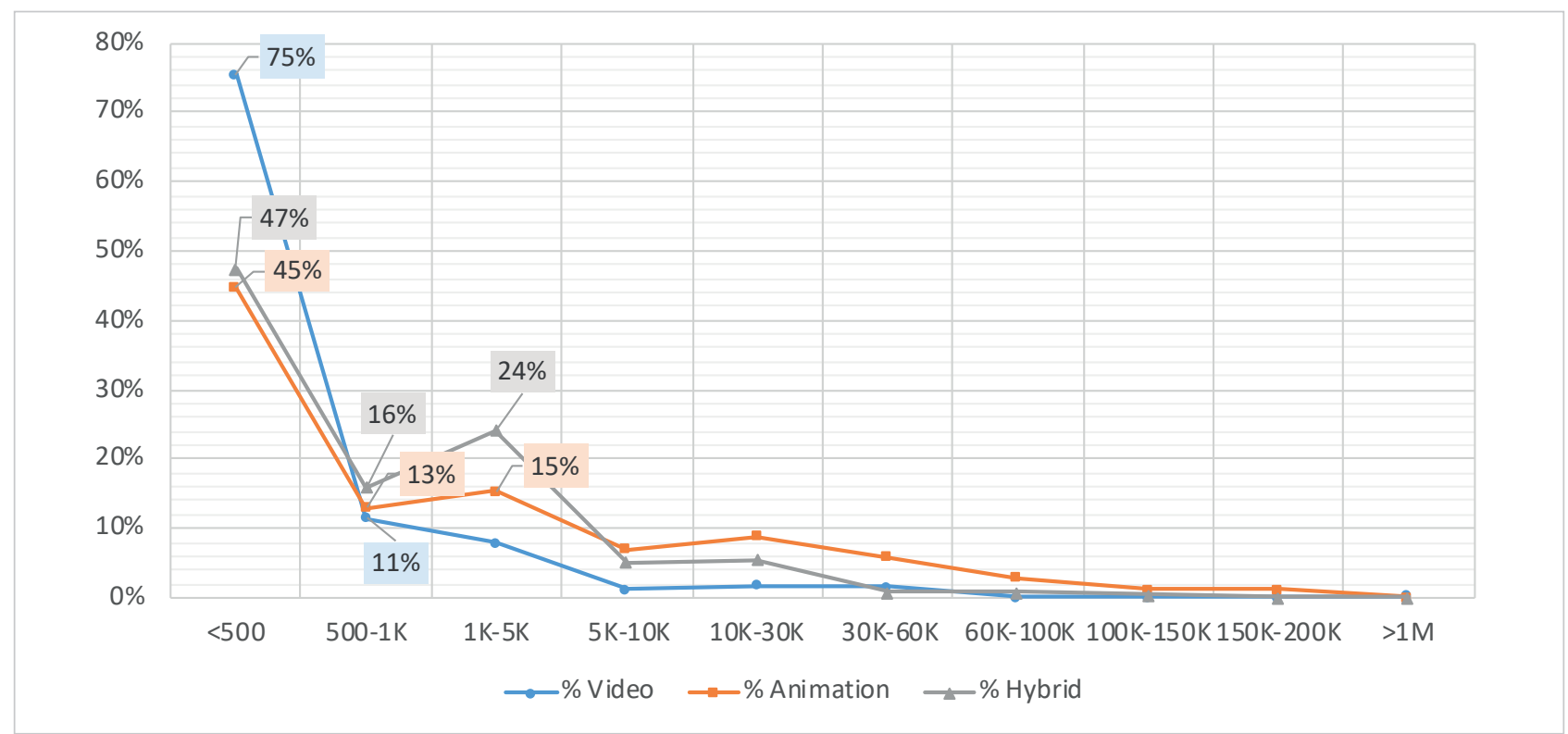

Figure 14. Number of views according to format (\%)

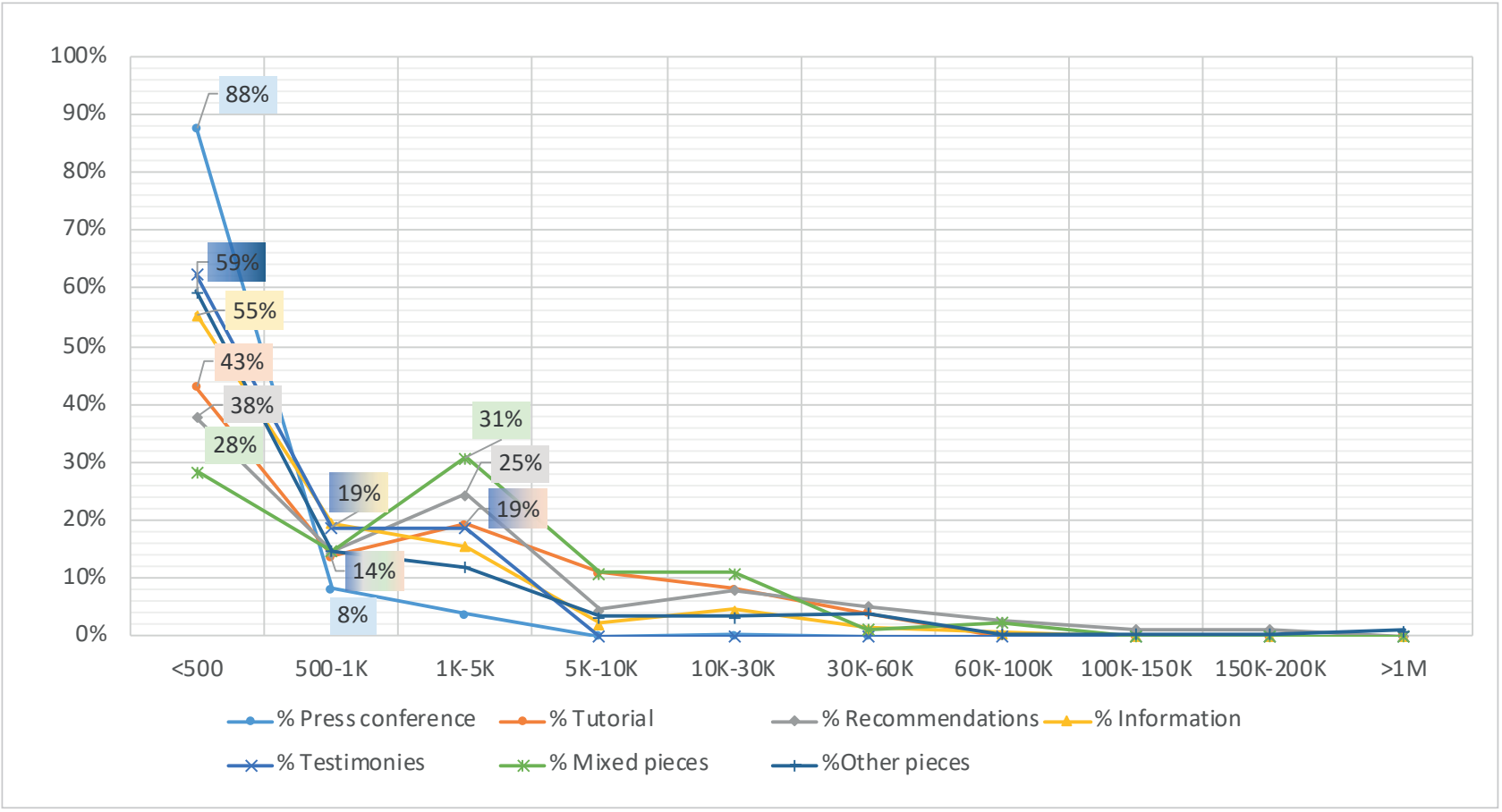

Figure 15. Number of views by content type (\%)

\section{Discussion and conclusions}

As well as attracting extraordinary attention (Casero-Ripollés, 2020), the Covid-19 crisis also accounted for almost all the health information emitted by the National Health System on YouTube in 2020. During this year, 1,035 pieces were produced, representing more than twice the content published in 2019 (505 pieces), with practically no others dealing with issues unrelated to the pandemic, barely $2 \%$.

Of the 17 official channels of the National Health System studied, the Ministry of Health was the institution that emitted the most content (29\%), while in the case of regional services, Catalonia (22\%) and Murcia (18\%) stand out, with these three together representing $69 \%$ of the total. At the other extreme are three regional institutions that, despite having an official YouTube channel, did not include any audiovisual pieces related to Covid-19 during 2020 (Cantabria, Castilla and Leon, and Extremadura). Among the channels that released such data (Table 1), the two with the highest number of subscribers were Andalusia and La Rioja, followed at some distance by the Ministry of Health, with less than half as many. At the other extreme are services with a few hundred followers. It is striking that, despite having the channel that broadcast the most content about Covid-19 and that received the most views, the Ministry of Health does not have a greater number of subscribers. 
The National Health System may seem to have used its YouTube channels to address societal demands for information, but these absolute data must be put into context. Although almost all the autonomous communities have a YouTube channel dedicated to health issues (except for Ceuta and Melilla, which depend directly on the Ministry of Health, and the Principality of Asturias health service, which does not have an official YouTube channel), $17.64 \%$ of the others did not use it at all to share information about the Covid-19 crisis. As noted above, more than half of the content was concentrated in three institutions, revealing the great disparity between the channels studied.

Regarding consumption and interaction, note that, as stated by Picazo-Sánchez (2016), establishing a single scale to qualify and classify views and/or reactions as normal, many, or few is complex, because of both the heterogeneity and the number of users, as well as the wide range of content emitted in the digital context. Therefore, the results for the number of views cannot be evaluated as positive or negative, despite the overwhelming differences between them. Of the 14 health institutions that used YouTube to emit information about Covid-19, 8 chose to use it as a one-way channel by disactivating comments. Obviously, they did this intentionally while using other networks such as Twitter or Facebook for bidirectional and participatory communication (Castillo-Esparcia; Fernández-Souto; Puentes-Rivera, 2020; Tur-Viñes; Gónzalez-Río, 2020).

Beyond their obligation to inform and guarantee a presence in an environment that is as competitive as the digital world, institutions must adapt their messages to the channel and target public to optimize access and consumption (Spain, 2011). Most of the audiovisual production by health institutions was pure videos with little editing (58\%), followed by hybrid pieces that combined real images with icons, texts, and other graphical elements, involving considerable assembly work (25\%). In absolute terms, animations were in the third and last place, representing $17 \%$ of the pieces studied. Despite being the least used format, the results show that it received the most follow-up from users based on the number of views and reactions (Table 4). In addition, this format increased most in percentage terms compared with previous years, from 45 in 2019 to 170 in 2020, representing an increase of 378\%. These data support the use of new formats and innovation in communication to guarantee wide exposure from the informational point of view (Ruivo-Manzano; Gomes-Franco-e-Silva, 2019). Also, as pointed out by Xifra (2020), the use of creative resources can make a difference in a digital context, where the visual prevails over the textual, dominated by the spectacular and striking (Rodríguez-Andrés, 2017). The increase and use of animations by health institutions are a reflection of all this.

Regarding the type of content, note that a large fraction of the audiovisual pieces broadcast on YouTube were press conferences (40\%). This trend seems to coincide with the government's communications strategy on Covid-19 during the early months of the crisis, which "focused mostly on the press conference format" ["centrad[a] en su mayoría en formato de ruedas de prensa"] (Castillo-Esparcia; Fernández-Souto; Puentes-Rivera, 2020, p. 2). Meanwhile, the content that offered recommendations and tutorials on health advice against Covid-19, representing $22 \%$ of the communication from the National Health System of Spain, are messages that propose a change in the viewer and active participation of society in the face of the pandemic by promoting healthy habits, encouraging the application of safety and hygiene measures to avoid infection, or advise on diet, physical activity, and mental health during the crisis, thereby promoting health education, which is a responsibility of public bodies (Spain, 1986; 2011). Thus, the production and dissemination of this type of information seems to be gaining in importance, since both the publication of educational content and their innovative and striking representation have increased notably.

This type of message was presented mainly in hybrid and animation formats and was of short duration, as established by Paredes-Otero (2019, p. 61), being less than 4 minutes, comprising direct, simple, entertaining, and engaging montages that are fully adapted to the most efficient type of audiovisual content for a channel such as YouTube (Costa, 2014). Compared with pure video, formats that include visual elements (many of them in motion) are increasingly required to transmit messages in a more attractive way and thereby capture the attention of the population and encourage their participation (Costa, 2014; Ruivo-Manzano; Gomes-Franco-e-Silva, 2019).

This reflects a tendency to share useful and practical information that motivates a proactive attitude in society so that, through a change in behavior, people can prevent disease and look after and improve their health. The analysis described above illustrates that an attempt was made in this crisis to adapt health communication to the actual context. In fact, as pointed out by Rodríguez-Andrés (2017), this represents the satisfaction of a fundamental requirement, although we insist that this cannot be considered true in absolute terms given the wide differences observed between the studied content. A double-faceted reading of the data obtained is thus interesting. This disparity is clearly illustrated when correlating the format and content variables (Figs. 5 and 6). This shows that, on the one
Animation is the format that increased most in percentage terms compared with previous years, almost quadrupling in 2020 and being used mainly to offer recommendations and advice on good habits 
hand, $68 \%$ of the pure videos published were press conferences, while $54 \%$ of the animations presented recommendations. On the other hand, if we focus on the types of content, we observe a stronger relationship between these and the format of each piece, revealing a clear trend, with $100 \%$ of press conferences being broadcast as pure video (without edition, even when published later), $61 \%$ of the recommendations taking the form of animations, and $88 \%$ of the testimonials being presented as hybrid pieces. This difference clearly indicates a preference to use a specific format depending on the type of information to be communicated. All of this is closely related to the responsibility of these public institutions to promote health education to the population, making use of content adapted thematically and formally to the informational needs and demands of citizens while respecting the social, cultural, and linguistic dimensions (Spain, 2011).

Considering that each act of communication is conditioned by the context in which it occurs, these findings present great opportunities and threats for the development of appropriate policies and strategies by such institutions. This analysis of the communication by the National Health System enables the identification of the main weaknesses and strengths of the audiovisual messages published by the health services via their official YouTube accounts throughout 2020 (Table 3).

Table 3. SWOT analysis of the audiovisual content studied

\begin{tabular}{|c|c|}
\hline Weaknesses & Threats \\
\hline $\begin{array}{l}\text { Lack of a unified strategy to determine the informational functions } \\
\text { that health systems must cover: } \\
\text { - A tendency to limit the use of the channel to a repository to host } \\
\text { audiovisual pieces }\end{array}$ & $\begin{array}{l}\text { Informational competition from other channels and media: } \\
\text {. Proliferation of hoaxes } \\
\text { - Loss of relevance of health institutions as authorized information } \\
\text { sources in a context of information overload }\end{array}$ \\
\hline $\begin{array}{l}\text { Lack of a unified strategy for the adaptation of the content to the } \\
\text { public }\end{array}$ & Few views and little interaction from the public \\
\hline Strengths & Opportunities \\
\hline $\begin{array}{l}\text { Increase in informative production in audiovisual format } \\
\text { Use of dynamic and eye-catching formats (hybrid pieces and anima- } \\
\text { tions) }\end{array}$ & $\begin{array}{l}\text { Importance of the institution as an authorized source and means of } \\
\text { communication } \\
\text { Use of YouTube as a channel for disseminating health information }\end{array}$ \\
\hline $\begin{array}{l}\text { Greater dissemination of information of a didactic/pedagogical natu- } \\
\text { re (recommendations and tutorials) }\end{array}$ & $\begin{array}{l}\text { Use of YouTube as a two-way medium to achieve greater interaction } \\
\text { with citizens }\end{array}$ \\
\hline
\end{tabular}

\section{Study limitations and future proposals}

During the analyzed period, many institutions, in addition to providing first-hand information on the progress of the virus, also gave advice and offered recommendations to guarantee the health of citizens during the pandemic. There is a trend towards homogenization and the unification of thematic and formal criteria within the channels but not between them: while some institutions tried to inform society through YouTube by sharing content related to health promotion and disease prevention, others used it exclusively as a means of advertising the activity of their political leaders. This shows that there is in fact great formal and thematic heterogeneity between the channels, which directly affects the role of each institution on this social network.

We consider that the problem of this supposed contradiction lies in how the object of study is approached and the results obtained. The raw data obtained by combining the channels provides an acceptable overview but does not reveal the specificities of each channel, which are remarkable as described above. This problem has already been identified in previous studies, which applied approaches of a much more selective nature based on the most visited videos on YouTube (Picazo-Sánchez, 2016; Tur-Viñes; Gónzalez-Río, 2020), very exhaustive and wide approaches (Orduña-Malea; Font-Julián; Ontalba-Ruipérez, 2020), and others with great depth (Paredes-Otero, 2019; Ruivo-Manzano; Gómes-Franco-e-Silva, 2019). This problem regarding specificity becomes evident when transforming the data obtained herein to draw up a list of the ten audiovisual pieces with the most views (Table 4).

The most popular audiovisual piece had more than 2.3 million views, followed by another with more than 1.5 million, according to data collected on 1 January 2021. Both were broadcast on the Ministry of Health channel and were advertising spots with a hybrid format. However, the large number of views of these pieces contrasts with the others, since the third most popular piece was viewed only 179,770 times, while the average for the 1,035 pieces studied was 7,487 views.

On the one hand, the commercial spot appears to be extraordinarily successful. However, it only represents $9.8 \%$ of the broadcast content; it is included in the Others category, and comprises $58.3 \%$ of the pieces. On the other hand, one must remember that all advertising spots are broadcast via many more media in addition to YouTube. Therefore, it is logical that its number of views will tend to be higher than for the others, as it is part of a transmedia communication strategy that uses synergy between channels to achieve greater dissemination. However, the format that seems to attract most attention from the public is animation, since it represents $60 \%$ of the most played content. However, once again, it is not the most produced, representing only $17 \%$ of the total. The same effect occurs with the type of content: $60 \%$ of the most popular pieces were recommendations, but they represented only $15 \%$ of the total. 
Table 4. Top ten pieces of the Spanish National Health System with the most views on YouTube (2020)*

\begin{tabular}{|c|c|c|c|c|c|c|c|c|c|c|c|}
\hline & & 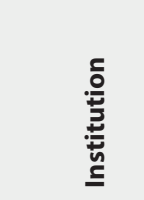 & $\stackrel{ \pm}{\stackrel{0}{0}}$ & 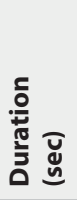 & $\sum_{j}^{n}$ & $\stackrel{y}{y}$ & $\frac{y}{y}$ & 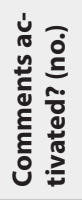 & $\begin{array}{l}\text { 艹 } \\
\text { हี } \\
\text { 유 }\end{array}$ & $\stackrel{\Perp}{\check{2}}$ & $\overrightarrow{\underline{r}}$ \\
\hline \multirow{10}{*}{ 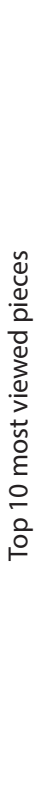 } & 1 & $\begin{array}{l}\text { Ministry of } \\
\text { Health }\end{array}$ & $10 / 09$ & 20 & $2,338,228$ & 200 & 301 & $\begin{array}{l}\text { Yes } \\
(0)\end{array}$ & Hybrid & Spot & $\begin{array}{l}\text { https://www.youtube.com/ } \\
\text { watch?v=iojY4d0JyTE }\end{array}$ \\
\hline & 2 & $\begin{array}{l}\text { Ministry of } \\
\text { Health }\end{array}$ & $17 / 03$ & 60 & $1,525,467$ & 2,540 & 1,845 & No & Hybrid & Spot & $\begin{array}{l}\text { https://www.youtube.com/ } \\
\text { watch?v=b6Fgddtx6aw }\end{array}$ \\
\hline & 3 & $\begin{array}{l}\text { Basque } \\
\text { Country }\end{array}$ & $13 / 03$ & 41 & 179,770 & 0 & 0 & No & Animation & Recommendations & $\begin{array}{l}\text { https://www.youtube.com/ } \\
\text { watch?v=9Zel5nbJkl4 }\end{array}$ \\
\hline & 4 & $\begin{array}{l}\text { Ministry of } \\
\text { Health }\end{array}$ & $10 / 12$ & 20 & 170,444 & 10 & 19 & $\begin{array}{l}\text { Yes } \\
(0)\end{array}$ & Hybrid & Spot & $\begin{array}{l}\text { https://www.youtube.com/ } \\
\text { watch?v=YUWVmiMowjY }\end{array}$ \\
\hline & 5 & $\begin{array}{l}\text { Ministry of } \\
\text { Health }\end{array}$ & $12 / 03$ & 77 & 151,189 & 505 & 115 & No & Animation & Recommendations & $\begin{array}{l}\text { https://www.youtube.com/ } \\
\text { watch?v=jPqIHzfrl8k }\end{array}$ \\
\hline & 6 & $\begin{array}{l}\text { Basque } \\
\text { Country }\end{array}$ & $04 / 03$ & 35 & 110,119 & 0 & 0 & No & Animation & Recommendations & $\begin{array}{l}\text { https://www.youtube.com/ } \\
\text { watch?v=dtTr8H_HXGA }\end{array}$ \\
\hline & 7 & $\begin{array}{l}\text { Basque } \\
\text { Country }\end{array}$ & $02 / 05$ & 25 & 103,766 & 0 & 0 & No & Animation & Recommendations & $\begin{array}{l}\text { https://www.youtube.com/ } \\
\text { watch?v=I7UmFIrLiZU }\end{array}$ \\
\hline & 8 & Catalonia & $18 / 12$ & 30 & 102,062 & 5 & 0 & No & Hybrid & Spot & $\begin{array}{l}\text { https://www.youtube.com/ } \\
\text { watch?v=eplbm4BWSsA }\end{array}$ \\
\hline & 9 & Catalonia & $18 / 12$ & 30 & 96,848 & 3 & 0 & $\begin{array}{l}\text { Yes } \\
(0)\end{array}$ & Animation & Recommendations & $\begin{array}{l}\text { https://www.youtube.com/ } \\
\text { watch?v=ih3OQj/KRmo }\end{array}$ \\
\hline & 10 & $\begin{array}{l}\text { Basque } \\
\text { Country }\end{array}$ & $02 / 05$ & 25 & 85,634 & 0 & 0 & No & Animation & Recommendations & $\begin{array}{l}\text { https://www.youtube.com/ } \\
\text { watch?v=aT3BVaNig28 }\end{array}$ \\
\hline
\end{tabular}

Beyond the decision of health institutions to use YouTube as a media channel that is open to comments from citizens and bearing in mind the low number of user reactions, we could not observe any correlation between the number of visits, likes and dislikes, and comments. Moreover, the views do not correspond to the number of likes and dislikes (compare, for example, the pieces released by the Ministry of Health).

Considering the number of subscribers, although the most viewed content was presented on channels with a considerable number of followers, they were not among the top two. This may be because both Andalusia and La Rioja, despite having the channels with the most subscribers, broadcast very little content about Covid-19 on YouTube.

However, a correlation appears between the number of views and the most successful pieces. However, this can be explained by their large number of views, with the top ten listed in Table 4 accounting for $63 \%$ of the total views of all the channels throughout 2020.

However, it cannot be concluded that there is a relationship between the number of views and the quantity of pieces published. Although the channels of the Ministry of Health and Catalonia produced the greatest amount of content and information on Covid-19, the Basque Country only published 31 messages ( $3 \%$ of the total), but three of them were among the top ten visited.

A comparison of the absolute data obtained from the analysis of all the content emitted by the National Health System on YouTube versus the most viewed pieces reveals that there does not seem to be a correlation between them. On the one hand, publishing a certain amount does not necessarily guarantee a high number of views. On the other, a sample of the most viewed content cannot be extrapolated to the entire universe of study, since it is not guaranteed to be representative.

Finally, this work is one of a small number of studies that have focused on the dissemination of health information via YouTube. Although some approaches have studied the presence or absence of this type of content on the channel (Orduña-Malea; Font-Julián; Ontalba-Ruipérez, 2020), we have not found any that focus on a specific broadcaster. Regarding the description of health messages on YouTube as a channel, we tried to relate what is expected, and even required, of the producer to the content disseminated. Contextualizing the object of study and addressing it exhaustively, since all the channels of the National Health System have been analyzed, allowed us to go beyond only a purely formal description of the disseminated pieces.

An approach of this type faces the double challenge of identifying an adequate methodology for the analysis of audiovisual content with these characteristics, and of not being able to use automated tools without
There is a trend towards homogenization and a unification of the thematic and formal criteria in each channel but not between them 
subsequent review (Orduña-Malea; Font-Julián; Ontalba-Ruipérez, 2020, p. 12). Both Arévalo-Salinas (2017) and Paredes-Otero (2019) already encountered this methodological problem, with both proposing an analytical form adapted to the audiovisual content found on YouTube. In fact, Arévalo-Salinas already suggested that this difficulty could be one of the reasons for the small number of scientific publications of this type. Tur-Viñes and González-Río (2020, p. 20) proposed a future line of research in which YouTube content was analyzed through the format and type of content, and degree of interaction. The analytical form designed and used in this research allows these proposed objectives to be met, but as in the case of the above-cited studies, it is limited to the health context.

It would be interesting to use both this methodology and the data presented herein to carry out an exhaustive analysis of each official channel of the National Health System individually, thus identifying the informative role that each adopts when spreading audiovisual messages on YouTube, and delving into the relationship between the format and type of the content, contextualized in each channel. We believe that this approach has proven its usefulness and could be used in future research in both public relations and journalism.

\section{References}

Andreu-Sánchez, Celia; Martín-Pascual, Miguel-Ángel (2020). “Imágenes falsas del coronavirus SARS-CoV-2 en la comunicación de la información al comienzo de la pandemia del Covid-19”. Profesional de la información, n. 29, v. 3, e290309. https://doi.org/10.3145/epi.2020.may.09

Arévalo-Salinas, Alex-Iván (2017). “Propuesta metodológica para el análisis de YouTube y su relación con los movimientos sociales". En: /l Congreso internacional Move.net sobre movimientos sociales y TIC, pp. 25-27. https://hdl.handle.net/11441/70614

Babbie, Earl; Wagner, William E.; Zaino, Jeanne (2018). Adventures in social research: data analysis using IBM SPSS statistics. California: SAGE. ISBN: 9781506362779

Batthyány, Karina; Cabrera, Mariana (coords.) (2011). Metodología de la investigación en ciencias sociales: apuntes para un curso inicial. Montevideo: CSE. ISBN: 9789974007697

Berganza-Conde, María-Rosa; García-Galera, María-del-Carmen (2005). “Metodología y uso estratégico de fuentes estadísticas y bases de datos de contenidos de medios". En: Berganza-Conde, María-Rosa; Ruiz-San-Román, José-A. (coords.). Investigar en comunicación: guía práctica de métodos y técnicas de investigación social en comunicación. Madrid: McGRaw-Hill. ISBN: 9788448198255

Bernat, María-Sofía (2020). “La pandemia, la vida cotidiana y la universidad”. Question, n. 1, e308. https://doi.org/10.24215/16696581e308

Blanco, Sonia; Palomo, Bella (2019). "Desencuentro de los periodistas con YouTube". El profesional de la información, v. 28, n. 4, e280411.

https://doi.org/10.3145/epi.2019.jul.11

Cantor-Silva, Mónica-Isabel; Pérez-Suárez, Eduardo; Carrillo-Sierra, Sandra (2018). "Redes sociales e identidad social". Aibi, Revista de investigación, administración e ingeniería, v. 6, n. 1, pp. 74-82.

https://doi.org/10.15649/2346030X.477

Casajús, Lucía; Giorgi, Noelia (2020). “El trabajo de los medios de comunicación universitarios en la pandemia”. Question, n. 1, e309.

https://doi.org/10.24215/16696581e309

Casero-Ripollés, Andreu (2020). "Impact of Covid-19 on the media system. Communicative and democratic consequences of news consumption during the outbreak". El profesional de la información, v. 29, n. 2, e290223.

https://doi.org/10.3145/epi.2020.mar.23

Castillo-Esparcia, Antonio; Fernández-Souto, Ana-Belén; Puentes-Rivera, Iván (2020). “Comunicación política y Covid-19. Estrategias del gobierno de España". El profesional de la información, v. 29, n. 4, e290419.

https://doi.org/10.3145/epi.2020.jul.19

Cinelli, Matteo; Quattrociocchi, Walter; Galeazzi, Alessandro; Valensise, Carlo-Michele; Brugnoli, Emanuele; Schmidt, Ana-Lucia; Zola, Paola; Zollo, Fabiana; Scala, Antonio (2020). "The Covid-19 social media infodemic". ArXiv, Cornell University.

https://arxiv.org/abs/2003.05004

Coombs, W. Timothy (2014). Ongoing crisis communication. Planning, managing, and responding. Florida: Sage. ISBN: 9781412983105 
Coombs, W. Timothy; Holladay, Sherry J. (2012). The handbook of crisis communciation. Malden: Wiley-Blackwell. ISBN: 9781444314885

Costa, Caio-Túlio (2014). “Um modelo de negócio para o jornalismo digital. Como os jornais devem abraçar a tecnologia, as a redes sociais e os serviços de valor adicionado". Revista de jornalismo ESPM, n. 9, pp. 51-115.

https://loja.espm.br/revista/gente-erramos-demais

Costa-Sánchez, Carmen (2010). “Crisis de salud pública. El derecho de los ciudadanos a estar informados”. Diálogos de la comunicación, v. 82, pp. 1-6.

https://dialnet.unirioja.es/descarga/articulo/3728253.pdf

Costa-Sánchez, Carmen (2011). "Tratamiento informativo de una crisis de salud pública: los titulares sobre Gripe A en la prensa española". Revista de comunicación la SEECI, n. 25, pp. 43-62.

https://doi.org/10.15198/seeci.2011.25.29-42

Costa-Sánchez, Carmen; López-García, Xosé (2020). “Comunicación y crisis del coronavirus en España. Primeras lecciones". Profesional de la información, v. 29, n. 3, e290304.

https://doi.org/10.3145/epi.2020.may.04

Costa-Sánchez, Carmen; Rodríguez-Vázquez, Ana-Isabel; López-García, Xosé (2015). “Del periodismo transmedia al replicante. Cobertura informativa del contagio de Ébola en España”. El profesional de la información, v. 24, n. 3, pp. $282-290$. https://doi.org/10.3145/epi.2015.may.08

Cui, Limeng; Lee, Dongwon (2020). "CoAID: Covid-19 healthcare misinformation dataset”. ArXiv, Cornell University. https://arxiv.org/abs/2006.00885

Downing, Joseph; Ahmed, Wasim; Vidal-Alaball, Josep; López-Seguí, Francesc (2020). Battling fake news and (in)security during Covid-19. E-International Relations.

https://www.e-ir.info/2020/04/23/battling-fake-news-and-insecurity-during-covid-19

España (1986). “Ley 14/1986, de 25 de abril, general de sanidad”. BOE, n. 102, 29 de abril. https://www.boe.es/eli/es/l/1986/04/25/14/con

España (2011). "Ley 33/2011, de 4 de octubre, general de salud pública”. BOE, n. 240, 5 de octubre. https://www.boe.es/eli/es/l/2011/10/04/33/con

Farhana, Khandaker-Mursheda; Mannan, Kazi-Abdul (2020). "Knowledge and perception towards novel coronavirus (Covid-19) in Bangladesh". International research journal of business and social science, v. 6, n. 2, pp. 76-88.

https://doi.org/10.2139/ssrn.3578477

Fernández-De-la-Hoz, Karoline (2014). “La comunicación en crisis sanitarias: perspectiva de las administraciones públicas". Revista española de comunicación en salud, v. 5, n. 1, pp. 14-19.

https://e-revistas.uc3m.es/index.php/RECS/article/view/3349/2001

Flores-Vivar, Jesús-Miguel (2017). Los elementos del ciberperiodismo. Madrid: Editorial Síntesis. ISBN: 9788490774595

Fusté-Forné, Francesc (2020). "Explicar el virus desde las portadas: un estudio de los periódicos españoles". Revista española de comunicación en salud, suplemento 1, pp. 210-217.

https://doi.org/10.20318/recs.2020.5409

Garzaniti, Ramiro; Díaz-Ledesma, Lucas-Gabriel; Navarro-Martínez, Ernesto (2020). “Discusiones marikas en tiempos de pandemia: [re]precarización de la vida, derecho a la salud y biopolítica”. Question, n. 1, e292.

https://doi.org/10.24215/16696581e292

González-Romo, Zahaira-Fabiola; Iriarte-Aguirre, Sofía (2020). “Análisis de la gestión de la comunicación de los influencers farmacéuticos españoles en instagram durante la pandemia del Covid-19". Revista española de comunicación en salud, suplemento 1, pp. 9-30.

https://doi.org/10.20318/recs.2020.5402

IAB Spain (2020). Estudio anual de redes sociales 2020.

https://iabspain.es/estudio/estudio-redes-sociales-2020

Ibáñez-Peiró, Ángel (2020). "La actividad informativa del gobierno español durante la emergencia sanitaria provocada por el coronavirus, Covid-19". Revista española de comunicación en salud, suplemento 1, pp. 304-318.

https://doi.org/10.20318/recs.2020.5441

Jardón-Vassallo, Carlos (2017). “La transformación digital en la comunicación de una organización profesional sanitaria”. En: Cuesta, Ubaldo; Peñafiel, Carmen; Terrón, José-Luis; Bustamante, Edilson; Gaspar, Sandra (coords.). Comunicación y salud. Madrid: Dextra, pp. 575-584. ISBN: 9788416898206 
Kemp, Simon (2020). Digital 2020: Global digital overview. We are social and Hootsuite. https://wearesocial-net.s3-eu-west-1.amazonaws.com/wp-content/uploads/common/reports/digital-2020/digital2020-global.pdf

Ky, Bonnie; Mann, Douglas L. (2020). “Covid-19 clinical trials: a primer for the cardiovascular and cardio-oncology communities". JACC, Basic to translational science, v. 5, n. 5, pp. 501-517.

https://doi.org/10.1016/j.jacbts.2020.04.003

Lagneaux, Milagros (2020). “Comunicación responsable en tiempos de pandemia”. Question, n. 1 (mayo), e284. https://doi.org/10.24215/16696581e284

Larson, Heidi (2018). "The biggest pandemic risk? Viral misinformation". Nature, v. 562, p. 309. https://doi.org/10.1038/d41586-018-07034-4

Lope-Salvador, Víctor; Gabelas-Barroso, José-Antonio; Bernad, Sagrario (2018). "Avatares de lo narrativo en la trivialización digital: el caso de YouTube". En: Marta-Lazo, Carmen (ed.). Calidad informativa en la era de la digitalización: fundamentos profesionales vs. infopolución. Madrid: Dykinson, pp. 49-64. ISBN: 9788491486701 https://doi.org/10.2307/j.ctv9zchsb.6

Manrique-Grisales, Jorge (2020). “La prensa en modo pandemia: una aproximación a las agendas informativas de expreso y el país sobre Covid-19". Revista española de comunicación en salud, suplemento 1, pp. 142-157. https://doi.org/10.20318/recs.2020.5450

Marfil-Carmona, Rafael; Osuna-Acedo, Sara; Ortiz-Sobrino, Miguel-Ángel (2018). "Entretenimiento de calidad en el ocio audiovisual y digital. Oportunidades para la educación en los medios y las industrias creativas del siglo XXI". En: Marta-Lazo, Carmen (ed.). Calidad informativa en la era de la digitalización: fundamentos profesionales vs. infopolución. Madrid: Dykinson, pp. 187-208. ISBN: 9788491486701

https://doi.org/10.2307/j.ctv9zchsb.15

Masip, Pere; Aran-Ramspott, Sue; Ruiz-Caballero, Carlos; Suau, Jaume; Almenar, Ester; Puertas-Graell, David (2020). "Consumo informativo y cobertura mediática durante el confinamiento por el Covid-19: sobreinformación, sesgo ideológico y sensacionalismo". El profesional de la información, v. 29, n. 3, e290312.

https://doi.org/10.3145/epi.2020.may.12

Mestre-Ortega, Pilar; Bote-Ruiz-de-Gordoa, Juan-José; Mira-Roldán, Amparo; Buendía-Domínguez, Rocío; Bravo-Hernández, Miguel-Ángel (2018). "Análisis de impactos de los medios de comunicación de los casos de la fiebre hemorrágica de Crimea-Congo en la Comunidad de Madrid (2016). El papel de la comunicación institucional en crisis de salud pública". Revista de comunicación y salud, v. 8, n. 1, pp. 99-109.

https://doi.org/10.35669/revistadecomunicacionysalud.2018.8(1).99-109

Micaletto-Belda, Juan-Pablo; Gallardo-Vera, Luis (2015). "La comunicación institucional en la crisis del Ébola en Europa: el caso de la crisis española de 2014 en sus inicios". Revista internacional de relaciones públicas, v. 5, n. 9, pp. 89-110. http://revistarelacionespublicas.uma.es/index.php/revrrpp/article/view/316

Montacute, Rebecca (2020). Social mobility and Covid-19. Implications of the Covid-19 crisis for educational inequality. London: Sutton Trust.

https://hdl.voced.edu.au/10707/540272

Nascimento-Junior, Lindberg; Reginato, Vivian-da-Silva-Celestino; Meliani, Paulo-Fernando; Menegon, Fabrício-Augusto; Ribeiro, Eduardo-Augusto-Werneck (2020). "Popularização das informações a partir do canal do YouTube do projeto Coronagis: O papel da divulgação científica em tempos de pandemia". Metodologias e aprendizado, v. 3, pp. 176-183.

https://doi.org/10.21166/metapre.v3i0.1360

Negredo, Samuel; Amoedo, Avelino; Vara-Miguel, Alfonso; Moreno, Elsa; Kaufmann, Jürg (2020). Digital news report. es 2020. Digital UNAV.

https://www.digitalnewsreport.es/2020/los-espanoles-conectados-se-informaron-por-igual-en-medios-y-redessociales-sobre-coronavirus-y-covid-19

Nespereira-García, Javier (2015). "La retórica como herramienta para la gestión y la comunicación del riesgo sanitario". Revista española de comunicación en salud, v. 6, n. 2, pp. 222-233.

https://e-revistas.uc3m.es/index.php/RECS/article/view/2941/1644

Nguyen, An; Catalán-Matamoros, Daniel (2020). "Digital mis/disinformation and public engagment with health and science controversies: Fresh perspectives from Covid-19". Media and communication (Lisboa), v. 8, n. 2, pp. 323-328.

https://doi.org/10.17645/mac.v8i2.3352 
Nielsen, Rasmus-Kleis; Fletcher, Richard; Newman, Nic; Brennen, J. Scott; Howard, Philip N. (2020). “Navigating the 'Infodemic': how people in six countries access and rate news and information about coronavirus". Reuters Institute for the Study of Journalism, University of Oxford.

https://reutersinstitute.politics.ox.ac.uk/sites/default/files/2020-04/Navigating\%20the\%20Coronavirus\%20Infodemic\%20FINAL.pdf

Orduña-Malea, Enrique; Font-Julián, Cristina I.; Ontalba-Ruipérez, José-Antonio (2020). “Covid-19: análisis métrico de vídeos y canales de comunicación en YouTube". El profesional de la información, n. 29, v. 4, e290401.

https://doi.org/10.3145/epi.2020.jul.01

Pakpour, Amir H.; Griffiths, Mark D.; Lin, Chung-Ying (2020). "Assessing psychological response to the Covid-19: The fear of Covid-19 scale and the Covid stress scales". International journal of mental health and addiction, $4 \mathrm{pp}$.

https://doi.org/10.1007/s11469-020-00334-9

Paredes-Otero, Guillermo (2019). "Análisis de YouTube como herramienta informativa en el periodismo español especializado en videojuegos". En: Paredes-Otero, Guillermo (ed.). Investigar las redes sociales. Un acercamiento interdisplinar. Sevilla: Egregius, pp. 52-72. ISBN: 9788417270902

https://hdl.handle.net/11441/90946

Peñafiel-Saiz, Carmen; Ronco-López, Milagros; Castañeda-Zumeta, Aitor (2020). "Ecología comunicativa en tiempos del coronavirus SARS-CoV-2. Del moméntum catastróphicum al virtus véritas". Revista española de comunicación en salud, suplemento 1 , pp. 328-338.

https://doi.org/10.20318/recs.2020.5466

Peña-Lillo, Macarena (2020). "Tweets de la autoridad sanitaria en Chile en los albores de la crisis del coronavirus". Revista española de comunicación en salud, suplemento 1, pp. 117-127.

https://doi.org/10.20318/recs.2020.5447

Percastre-Mendizábal, Salvador; Pont-Sorribes, Carles; Suau-Gomila, Guillem (2019). “La gestión comunicativa en redes sociales digitales de la emergencia del Ébola en España”. Revista española de comunicación en salud, suplemento 1, pp. 80-90. https://doi.org/10.20318/recs.2019.4437

Picazo-Sánchez, Laura (2016). "Patrones del comportamiento viral en vídeo. Modelos de contagio viral en YouTube". Documentación de las ciencias de la información, v. 39, pp. 313-331.

https://doi.org/10.5209/DCIN.54421

Quinn, Paul (2018). 'Crisis communication in public health emergencies: the limits of 'legal control' and the risks for harmful outcomes in a digital age". Life sciences, society and policy, v. 14, n. 4, pp. 1-40.

https://doi.org/10.1186/s40504-018-0067-0

Ramón-Fernández, Francisca (2020). “Comunicación y noticias falsas en relación al Covid-19: algunas reflexiones sobre la información, la desinformación y propuestas de mejora”. Revista española de comunicación en salud, suplemento 1 , pp. 253-264.

https://doi.org/10.20318/recs.2020.5375

Rodríguez-Andrés, Roberto (2017). "Cómo diseñar planes de comunicación para organizaciones sanitarias”. En: Cuesta, Ubaldo; Peñafiel, Carmen; Terrón, José-Luis; Bustamante, Edison; Gaspar, Sandra (coords.). Comunicación y salud. Madrid: Dextra, pp. 367-378. ISBN: 9788416898206

Ruivo-Manzano, Fabio; Gomes-Franco-e-Silva, Flávia (2019). “YouTube como herramienta de refuerzo de marca para la Agencia EFE. Pilares para el éxito en plataformas de vídeos digitales". Hipertext.net, n. 18, pp. 35-46.

https://doi.org/10.31009/hipertext.net.2019.i18.04

Salaverría, Ramón; Buslón, Nataly; López-Pan, Fernando; León, Bienvenido; López-Goñi, Ignacio; Erviti, María-Carmen (2020). "Desinformación en tiempos de pandemia: Tipología de los bulos sobre la Covid-19". Profesional de la información, n. 29, v. 3, e290315.

https://doi.org/10.3145/epi.2020.may.15

Salva, Eumelia P.; Villarama, José-Benito; López, Edmundo B.; Sayo, Ana-Ria; Villanueva, Annavi-Marie G.; Edwards, Tansy; Han, Su-Myat; Suzuki, Shuichi; Seposo, Xerxes; Ariyoshi, Koya; Smith, Chris (2020). "Epidemiological and clinical characteristics of patients with suspected Covid-19 admitted in metro Manila, Philippines". Tropical medicine and health, v. 48, n. 51. https://doi.org/10.1186/s41182-020-00241-8

Sánchez-Duarte, José-Manuel; Magallón-Rosa, Raúl (2020). “Infodemia y Covid-19. Evolución y viralización de informaciones falsas en España". Revista española de comunicación en salud, suplemento 1, pp. 31-41.

https://doi.org/10.20318/recs.2020.5417

Seeger, Matthew W.; Reynolds, Barbara (2008). "Crisis communication and the public health: integrated approaches and new imperatives". In: Seeger, Matthew; Sellnow, Timothy; Ulmer, Robert (eds.). Crisis communication and the public health. New Jersey: Hampton Press, pp. 3-20. ISBN: 9781572737506 
Singh, Lisa; Bansal, Shweta; Bode, Leticia; Budak, Ceren; Chi, Guangqing; Kawintiranon, Kornraphop; Padden, Colton; Vanarsdall, Rebecca; Vraga, Emily; Wang, Yanchen (2020). "A first look at Covid-19 information and misinformation sharing on Twitter". ArXiv, Cornell University.

https://arxiv.org/pdf/2003.13907.pdf

Stein, Murray B. (2020). "Covid-19 and anxiety and depression in 2020". Depression and anxiety, n. 37, v. 4, p. 302. https://doi.org/10.1002/da.23014

Thelwall, Mike; Thelwall, Saheeda (2020). "Covid-19 tweeting in English: gender differences". El profesional de la información, n. 29, v. 4, e290301.

https://doi.org/10.3145/epi.2020.may.01

Tur-Viñes, Victoria; González-Río, María-José (2020). “Is YouTube being used to its full potential? Proposal for an indicator of interactivity for the top youtuber content in Spanish". Communications, De Gruyter Mouton. https://doi.org/10.1515/commun-2019-0127

Xifra, Jordi (2020). “Comunicación corporativa, relaciones públicas y gestión del riesgo reputacional en tiempos del Covid-19". El profesional de la información, v. 29, n. 2, e290220.

https://doi.org/10.3145/epi.2020.mar.20

Ziems, Caleb; He, Bing; Soni, Sandeep; Kumar, Srijan (2020). "Racism is a virus: anti-Asian hate and counterhate in social media during the Covid-19 crisis". ArXiv, Cornell University.

https://arxiv.org/abs/2005.12423

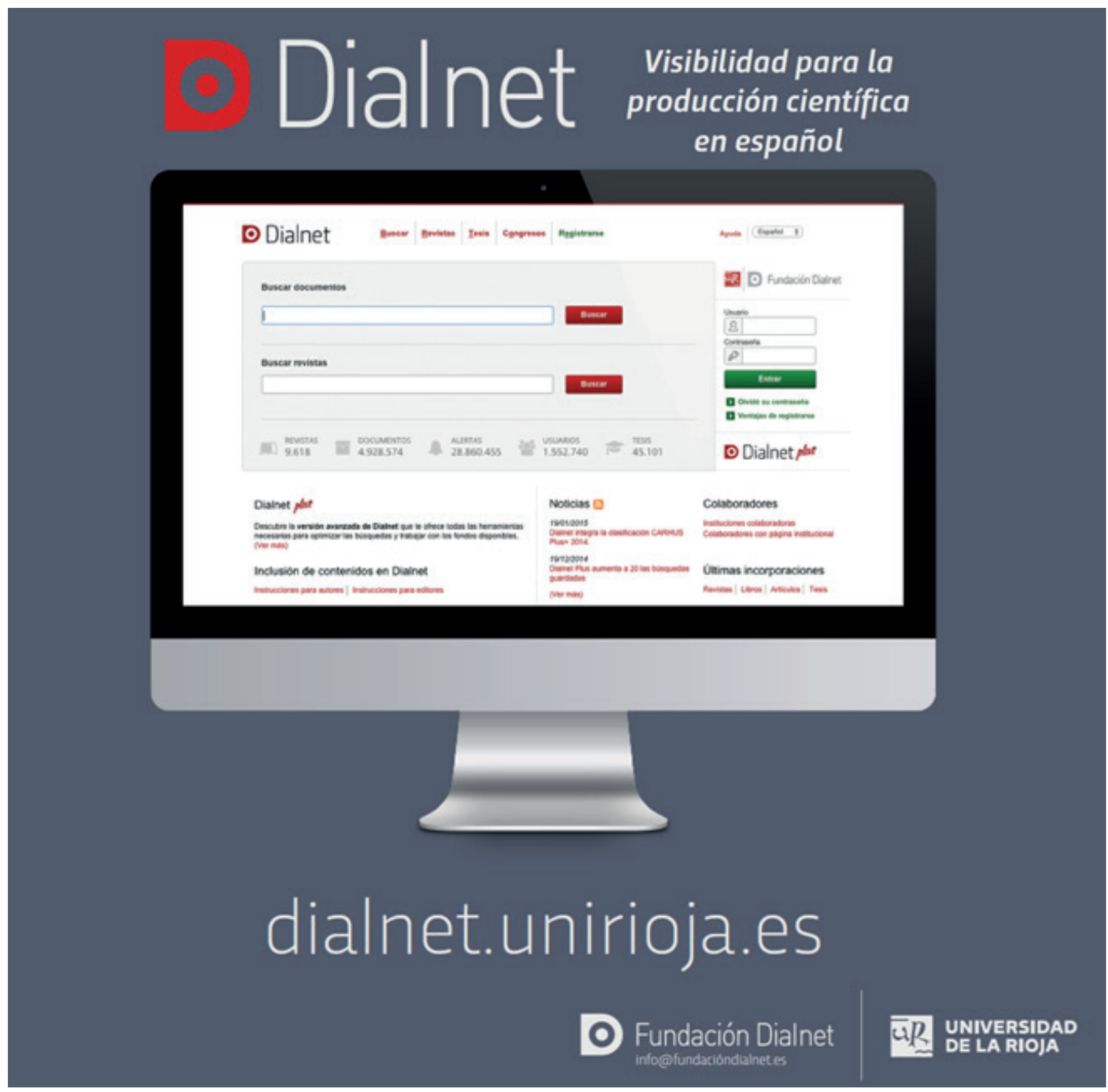

